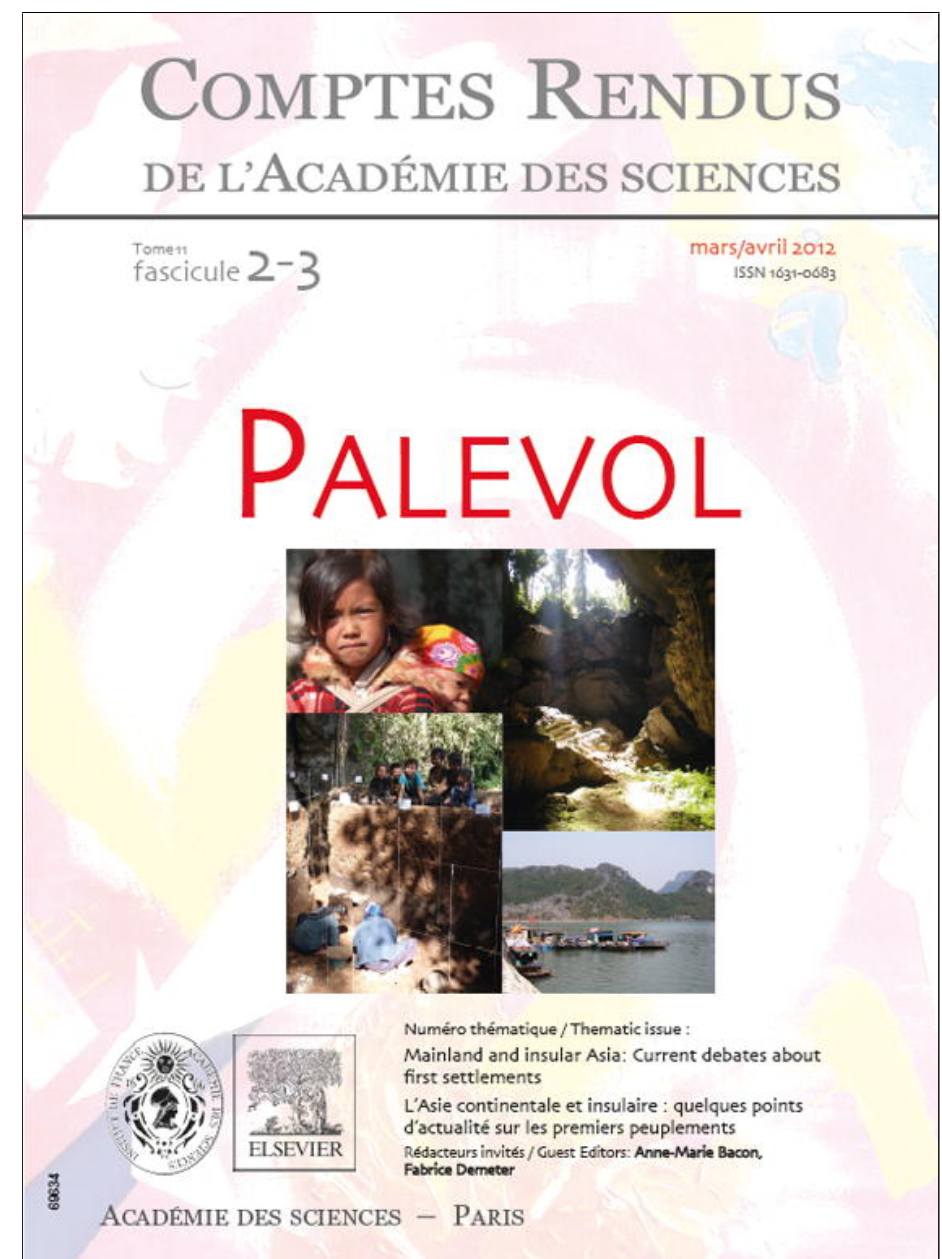

This article appeared in a journal published by Elsevier. The attached copy is furnished to the author for internal non-commercial research and education use, including for instruction at the authors institution and sharing with colleagues.

Other uses, including reproduction and distribution, or selling or licensing copies, or posting to personal, institutional or third party websites are prohibited.

In most cases authors are permitted to post their version of the article (e.g. in Word or Tex form) to their personal website or institutional repository. Authors requiring further information regarding Elsevier's archiving and manuscript policies are encouraged to visit:

http://www.elsevier.com/copyright 
Human palaeontology and prehistory

\section{The ethnolinguistic identity of the domesticators of Asian rice}

\section{L'identité ethnolinguistique des domestiquateurs du riz asiatique}

\section{George van Driem}

Université de Berne, institut de linguistique, Länggassstrasse 49, CH 3000 Berne 9, Switzerland

\section{A R T I C L E I N F O}

\section{Article history:}

Received 14 June 2011

Accepted after revision 8 July 2011

Available online 22 September 2011

Written on invitation of the Editorial Board

\section{Keywords:}

Ethnolinguistic identity

Rice

Asia

\section{Mots clés :}

Identité ethnolinguistique

Riz

Asie

\begin{abstract}
A B S T R A C T
Linguistic palaeontology permits the identification of two language families whose linguistic ancestors pose the likeliest candidates for the original domesticators of rice, viz. Hmong-Mien and Austroasiatic. In the 2009 model, the ancient Hmong-Mien was identified as the primary domesticators of Asian rice, and the ancient Austroasiatics as the secondary domesticators. Recent rice genetic research leads to the modification of this model for rice domestication, but falls short of identifying the original locus of rice domestication. At the same time, the precise whereabouts of the Austroasiatic homeland remains disputed. Linguistic evidence unrelated to rice agriculture has been adduced to support a southern homeland for Austroasiatic somewhere within the Bay of Bengal littoral. The implications of new rice genetic research are discussed, the linguistic palaeontological evidence is reassessed, and an enduring problem with the archaeology of rice agriculture is highlighted.

(c) 2011 Académie des sciences. Publié par Elsevier Masson SAS. Tous droits réservés.
\end{abstract}

\section{R É S U M É}

La paléontologie linguistique permet l'identification de deux familles de communautés linguistiques, dont les ancêtres sont vraisemblablement les cultivateurs originaux du riz asiatique, c'est-à-dire le hmong-mien et l'austroasiatique. Selon le modèle de 2009, les anciens hmong-miens furent identifiés comme les domesticateurs primaires du riz asiatique, et les anciens austroasiatiques comme les domesticateurs secondaires. Des recherches génétiques récentes aboutissent à une modification de ce modèle de la domestication du riz, mais ne permettent pas encore d'identifier le site géographique de l'origine de la riziculture. En même temps, le site géographique exact du berceau de la famille austroasiatique reste contesté. Des preuves linguistiques non liées à la riziculture sont présentées pour appuyer l'hypothèse d'un berceau méridional de l'austroasiatique quelque part sur le littoral du golfe du Bengale. Les implications des nouvelles recherches génétiques sur le riz asiatique sont discutées, les données dans le domaine de la paléontologie linguistique sont réexaminées, et un problème persistant portant sur l'archéologie de la riziculture est expliqué.

(c) 2011 Académie des sciences. Publié par Elsevier Masson SAS. Tous droits réservés.

\section{The ever morphing rice controversy}

In 1883, the director of the botanical garden in Geneva, Alphonse-Louis-Pierre Pyrame de Candolle, argued that the origin of cultivated rice lay in China and that rice was introduced to India from China (1883). Nikolaï Ivanovič Vavilov 
(1926) later argued against a Chinese origin for rice and contended instead that the origin of Asian rice lay in India, whence the crop had spread to China and Japan. The controversy has waged ever since, but has taken on a new shape since the application of molecular genetics to the question ${ }^{1}$.

Some molecular genetic studies have supported the hypothesis that Asian rice was domesticated twice (Kovach et al., 2007, 2009; Sweeney and McCouch, 2007), even thrice (Londo et al., 2006). According to this view, an eastern domestication of the perennial swamp species O. rufipogon led to the development of the japonica cultivar of $O$. sativa. The mutation sh4 led to the partial development of the abcission zone where the mature grain detaches from the pedicle, and the reduced brittleness of the rachides reduced grain shattering. Subsequently, human domestication also favoured genes coding for a whiter grain pericarp (rc) and erecter stalks (Prog1).

Further west, according to this view, the domestication of the annual self-pollinating nivara ecotype of O. rufipogon led to the development of the indica cultivar of O. sativa. Crucially, the domestication of indica rice was rendered possible by the introduction of the domesticated japonica traits sh4, rc and Prog1 into the nivara gene pool through introgressive hybridisation, involving backcrossing with the previously domesticated japonica cultivar. The javanica cultivar was demonstrated to be a tropical variety of japonica, and some long-grained aromatic varieties, such as Indian bāsmati rice, have likewise been shown to derive from japonica (Garris et al., 2005; Parsons et al., 1999). By contrast, Thai jasmine rice is an indica variety with the fragrant allele of the betaine aldehyde dehydrogenase gene BADH2 introduced by introgression (Kovach et al., 2009). Upland or dry-cultivated rice (Nepali ghaiyā, Bengali āuś) is genetically more closely affiliated to indica than to japonica rice, and some have argued that upland rice resulted from yet a third domestication (Londo et al., 2006).

An alternative view has been presented in a recent study (Molina et al., 2011). The evidence presented indicates that there was just a single domestication event for Asian rice some time between 13,500 and 8200 years ago, but the authors are unable to exclude "the possibility that both indica and japonica originated from highly differentiated O. rufipogon gene pools that were not sampled" (op cit., p. 5). O. rufipogon is a highly diverse species which has long been undergoing a process of speciation. Moreover, the authors stress that the genetic signatures of the original domestications could have been obscured by human selective breeding, possibly entailing massive admixture or prolonged bottlenecks during the domestication processes and so hampering population genetic attempts at reconstructing the evolutionary history of cultivated rice.

The newer evidence adduced by Molina et al. (2011) also indicates that either the wild rufipogon population of the Indian Subcontinent and mainland Southeast Asia or otherwise some now extinct rufipogon population was ancestral to all domesticated rice. A larger sampling will

\footnotetext{
${ }^{1}$ How this controversy about the original homeland of rice domestication has influenced historical linguistic discourse is discussed in the Himalayan handbook (van Driem, 2001: 324-327 et passim).
}

be needed to support the latter finding with greater confidence. The authors' conjecture that rice was domesticated in the Yangtze river basin is therefore not supported by their phylogenetic data, but relies directly on the currently available archaeological evidence. An enduring problem with rice agriculture archaeology is addressed below, in Section 3.

\section{The two usual suspects}

Linguistic palaeontology, a term introduced by Adolphe Pictet in 1859, is an attempt to understand the ancient material culture of a language family on the basis of the lexical items which can be reliably reconstructed for the common ancestral language. The reflexes of the reconstructed roots should be reflected across the various branches of the family, and their phonological development should be historically regular. The two language families which reflect rice agriculture terminology robustly are Hmong-Mien and Austroasiatic.

Strecker's (1987) Hmong-Mien phylogeny recognises three branches, i.e. Hmongic (Miáo), comprising 27 linguistic subgroups arranged in an articulate tree structure, Mienic (Yáo), comprising six subgroups arranged in a tree structure, Ho Nte (Shē) comprising two subgroups, and a fourth entity, the language Na-e, the precise classification of which is problematic. The antiquity of the linguistic phylum as a whole, and indeed the antiquity of most major linguistic phyla, remain largely a matter of conjecture. Indirect arguments like the relative chronology of branching and the possible dating of loans figure prominently in historical linguistics in the absence of absolute dating techniques comparable to, say, a radiocarbon date. However, the perennial inability of linguists to establish a genetic relationship between Hmong-Mien and any other major linguistic Asian phylum is compatible with the assumption that the common Hmong-Mien proto-language could represent a stage roughly coetaneous with Proto-Austroasiatic or Proto-Tibeto-Burman.

Martha Ratliff $(2004)^{2}$ identifies ten rice cultivation etyma as reconstructible to the Proto-Hmong-Mien level: *hnrəayH "cooked rice", *hnon "rice head, head of grain", *mblou "rice plant, paddy", *mphirkk "chaff", *mblut "glutinous”, *ljin “paddy field”, *ljim “sickle”, * ykjuəX “rice cake”, *tuX "husk/pound rice" and *tsjenH "rice steamer". Five rice agriculture terms are reconstructible to the Proto-Hmongic level: *S-phjæ ${ }^{C}$ "chaff", "mbljæ ${ }^{C}$ "have food with rice", *2rin ${ }^{\mathrm{A}}$ "dry (rice) in sun, ${ }^{*}$ ntsuw ${ }^{\mathrm{C}}$ "husked rice" and ${ }^{*} \mathrm{tsh}^{\mathrm{B}}{ }^{\mathrm{B}}$ "husked rice or millet". The two roots *hmei ${ }^{\mathrm{B}}$ "husked rice"

\footnotetext{
2 I thank Martha Ratliff for sharing with me the index of her forthcoming handbook on Hmong-Mien historical phonology, which is slated for publication by Pacific Linguistics in Canberra. I thank Bill Baxter and Wolfgang Behr for discussion of the Old Chinese forms. The reconstructed forms attempt to conform to the latest version of Bill Baxter and Laurent Sagart's Old Chinese reconstruction of 20 February 2011, soon to be published. Many thanks to Scott DeLancey and Wolfgang Behr for helpful editorial suggestions, and I cordially thank Anne-Marie Bacon for the Holocene distribution maps.
} 
and the rice measure etymon ${ }^{*} \mathrm{hrau}^{\mathrm{A}}$ are reconstructible to the Proto-Mienic level.

Six of the ten forms reconstructible Proto-Hmong-Mien etyma are also found in Old Chinese, where, however, they are they more likely to represent ancient loans into Sinitic from Hmong-Mien rather than the other way around (pace Ratliff, 2004: 158-159). First of all, the Old Chinese forms 秫 *molut (shú) “glutinous millet” (i.e. not rice), 田*1'in (tián) “field”, 鎌 *[r]em (lián) “sickle”, 粔 *[g](r)a(k)-s (jù)

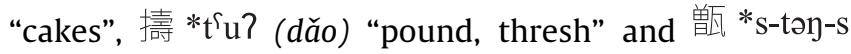
(zèng) "steamer" are not reconstructible to Tibeto-Burman, of which Sinitic is but a subgroup (van Driem, 2005, 2007). Similarly, Ratliff relates Proto-Hmongic $* 2 j \varepsilon \eta^{A}$ "seedling" and Proto-Mienic * $\mathrm{jja \eta}^{\mathrm{A}}$ "seedling" to Middle Chinese 秧 $*$ ?jang (yāng), evidently due to a discrepancy in vocalism between the Hmongic and Mienic forms, and relates Proto-Hmongic ${ }^{*}{ }^{\mathrm{j} \varepsilon}{ }^{\mathrm{A}}$ "rice measure" to Old Chinese 量 $*[\mathrm{r}]$ ay (liàng, liáng), but again neither etymon is well reflected in Tibeto-Burman outside of Sinitic. Moreover, not only are the earliest textual attestations of the Chinese forms $\boxplus$ *1 in “field”, 粔 * [g](r)a(k)-s “cakes”,

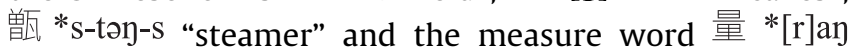
absolutely ambiguous as to what kind of grain they refer to,

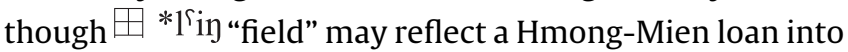
Sino-Bodic rather than just Sinitic. Furthermore the form 粔 * $[\mathrm{g}](\mathrm{r}) \mathrm{a}(\mathrm{k})$-s “cakes" is actually not an Old Chinese form, for its first known attestation occurs in the poetry anthology of the feudal state of Chǔ, entitled 楚辭 Chǔcí, dating from the Hàn period, whereas 鎌 *[r]em “sickle" likewise first occurs in the Hàn period as a western dialect word (Wolfgang Behr, personal communication).

The Proto-Mienic *hmei ${ }^{\mathrm{B}}$ "husked rice" appears to correspond to Old Chinese ${ }^{\prime} *[\mathrm{~m}]^{\Upsilon}{ }^{\mathrm{ij}}$ ? $(\mathrm{m} \check{\mathrm{i}}$ ), and rice terms containing a bilabial nasal initial appear in other languages in the East of the Tibeto-Burman area, e.g. Bái $m e^{33}$ "husked rice", Jinuo $a^{44} m \varepsilon^{44}$ "rice", Black Lahu $m i^{33}$ "paddy", Nusu $m e^{33} m e^{31}$ "rice", Garo mi, Dimasa mai "rice", Tangkhul ma "paddy", Sgaw Karen me "boiled rice". However, the meanings of these forms are disparate, viz. paddy, hulled rice, boiled rice, and the forms may represent mere look-alikes, since no regular phonological correspondence is yet known to obtain between them. Benedict (1972: 149) set up a Bodo-Koch proto-form *mey or *may "rice, paddy", which Matisoff later inflated to Tibeto-Burman "*ma $\Leftrightarrow$ *may or *mey" (2003: 216, 231) by adding a "monophthongal allofam" and stressing the uncertainty of the rhyme. In fact, no rice agricultural terminology can be confidently reconstructed for the Tibeto-Burman phylum as a whole, an issue addressed by Blench (2009).

The second language family aside from Hmong-Mien with an impressive reconstructible repertoire of rice agriculture terms is Austroasiatic. Gérard Diffloth (2005) has adduced the following eleven reconstructible Austroasiatic roots: *(kə)ba:? "rice plant", *royko:? "rice grain", *cəクka:m "rice outer husk", *kəndək "rice inner husk", *phe:? "rice bran", *təmpal "mortar", *jənre? "pestle", *jəmpiər "winnowing tray", *gu:m "to winnow", *jərmuəl "dibbling stick" and *kəntu:? "rice complement", i.e. accompanying cooked food other than rice. The comparative historical study of Austroasiatic is not as advanced or, for that matter, as tractable as that of Hmong-Mien, and perhaps for these reasons the current repertoire of reconstructible Austroasiatic rice agricultural terms is slightly more modest.

Rice cultivation terminology could have been borrowed into Sinitic from ancient Hmong-Mien rice cultivators at a time when Proto-Sinitic millet growers came into increasing contact with their southern neighbours. The main split in the Hmong-Mien family is between Hmongic and Mienic, and the scattered distributions of modern communities of either branch have approximately the same geographical range, which is roughly bisected by the Pearl River. On the basis of the historical sources, it has long been mooted that the geographical centre of gravity of the family would originally have lain further north along the middle Yangtze (Cushman, 1970). There is currently no palaeobotanical evidence for the co-cultivation of rice and foxtail millet along the middle Yangtze until around 3800 BC (Nasu et al., 2006). This brings us to a problem with rice agriculture archaeology.

\section{The problem with the archaeology of rice agriculture}

The archaeology of rice agriculture is plagued by an empirical quandary. Archaeologists have looked for the remains of early rice agriculture and indeed found them at some sites and not at some others. The recovered remains of early cultivated rice are of differing antiquity and reflect distinct stages of domestication. Unsurprisingly, archaeologists have not found the remains of early rice agriculture in those places where they have not yet looked. Vast swathes of Asia covering the areas identified by rice geneticists (Londo et al., 2006, Molina et al., 2011) as harbouring likely sites for the domestication of Asian rice have not been subjected to systematic archaeological and palaeobotanical investigation.

Palaeobotanical evidence for an early domestication of Asian rice might as yet turn up in Northeastern India and the Indo-Burmese borderlands, regions which have maintained highly diverse rice cultures to the present day. At least five species of wild rice are native to Northeastern India, viz. O. nivara, O. officianalis (O. latifolia), O. perennis (O. longistaminata), O. meyeriana (O.granulata) and $O$. rufipogon, and reportedly over a thousand varieties of domesticated rice are currently in use in the region (Hazarika, 2005, 2006). Despite the archaeological work conducted in the Ganges and Yangtze basins, much of the archaeology of ancient rice agriculture simply remains unknown because little or no substantive work has been done on the Neolithic in the most relevant areas, e.g. Northeastern India, Bangladesh, the Indo-Burmese borderlands and Burma. One archaeologist of cereal cultivation in China has already stressed the need to expand the scope of research beyond the Yangtze river basin into these areas, e.g. Lu (2006, 2009). 


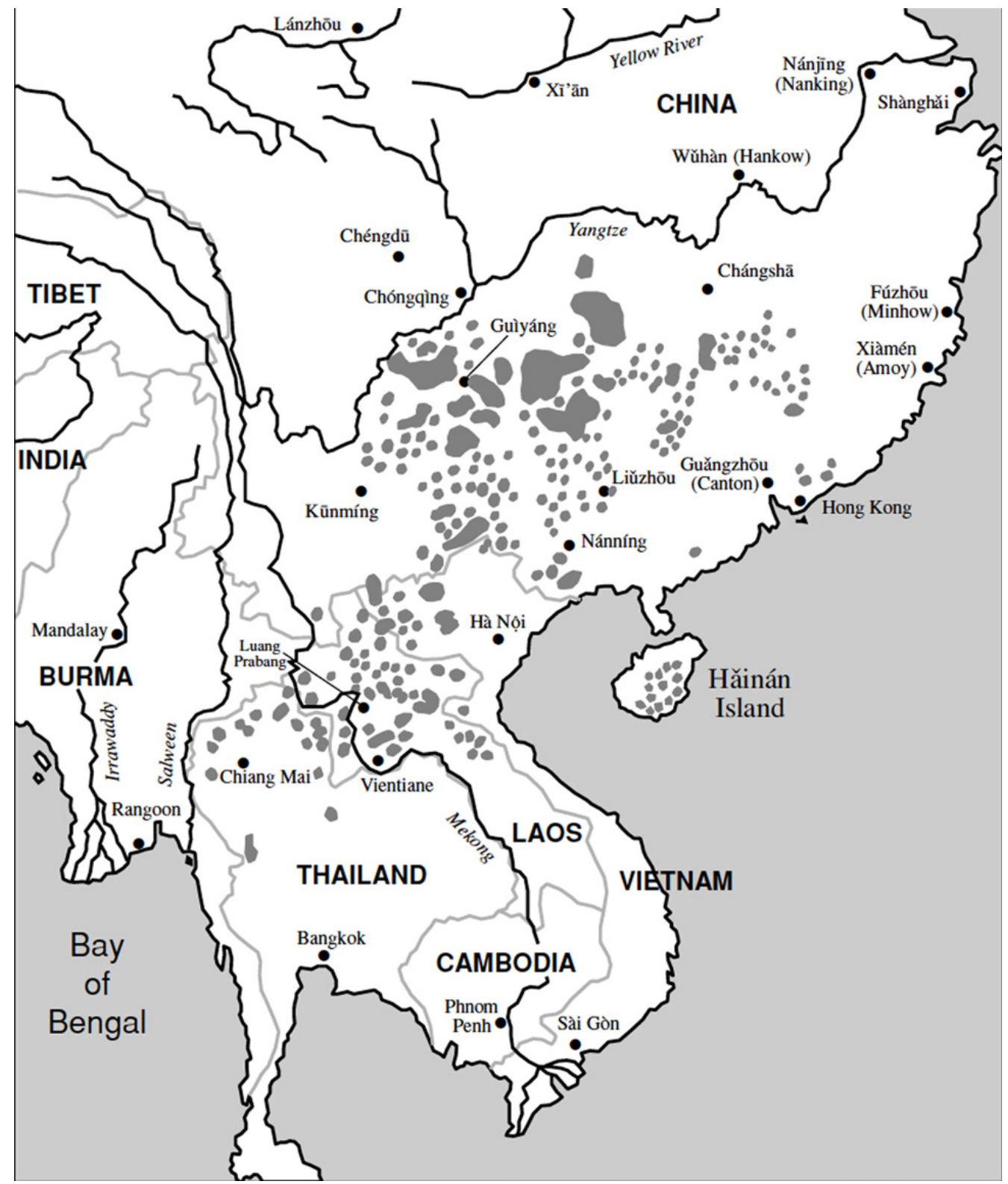

Fig. 1. The geographical distribution of modern Hmong-Mien language communities (van Driem, 2001: 319).

Fig. 1. Distribution géographique des communautés de langues modernes hmong-mien (van Driem, 2001: 319).

A related but distinct empirical issue is the archaeological recoverability of rice agriculture sites. The traces of ancient farming communities would tend to have been better preserved in the hill tracts surrounding the Brahmaputran flood plains than on the fertile fields themselves. Even in East Asia, most salvageable rice agriculture sites are in the foothills or at the base of the foothills (Nakamura, 2010). Yet the earliest rice-based cultures may first have developed on those very flood plains. Perhaps the remains of the first rice cultivating cultural assemblages lie buried forever in the silty sediments of the sinuous lower Brahmaputran basin. Maybe the palaeobotanical evidence for the earliest domestication of rice was washed out by the Brahmaputra long ago and now lies submerged in the depths of the Bay of Bengal.

By comparison, the absence of evidence for early rice agriculture of great antiquity in mainland Southeast Asia, despite the relatively more well researched archaeology of the region, presently embarrasses those who have lately taken to espousing Robert von Heine-Geldern's 1917 homeland theory for Austroasiatic around the lower course of the Mekong. However, the fact that the archaeology of Northeastern India, the Indo-Burmese borderlands and the northern Bay of Bengal littoral is virtually unresearched does not compromise homeland proposals in this region. As the old saw has it, the absence of evidence is not the evidence of absence. Political, cultural, geographical and logistic factors appear to have conspired to impede intensive archaeological research in a vast area extending from the lower Brahmaputran basin to the Tenasserim.

Against this background, the archaeology of rice agriculture has nonetheless produced important results. The domestication of japonica rice through genetic modification by selective breeding was possibly effectuated along 
the Yangtze around the beginning the fifth millennium BC by people, who previously relied far more heavily on the collecting of acorns, water chestnuts and foxnuts before becoming reliant on rice cultivation (Fuller and Qin, 2009; Fuller et al., 2007, 2009; Nakamura, 2010; Ruddiman et al., 2008; Zhao, 2010). Rice cultivation reached the Yellow River basin during the third millennium BC (Crawford and Shen, 1998) and Formosa and Vietnam between 2500 and 2000 BC (Higham and Lu, 1998), but only spread throughout the Indo-Chinese peninsula between 1500 and 500 BC (Weber et al., 2010). It has been claimed that rice may have been cultivated in the Gangetic basin as early as 7000 BC (Agrawal, 2002; Pal, 1990; Sharma et al., 1980), but the current evidence for the actual domestication of rice in the middle Ganges dates from no earlier than the second half of the third millennium BC.

\section{The 2009 model and the Hmong-Mien homeland}

On the basis of evidence presented at the 4th International Conference on Austroasiatic Linguistics in 2009 (van Driem, in press), the early Hmong-Mien were identified as the original domesticators of japonica rice and the ancient Austroasiatics as the original domesticators of indica rice from the wild precursors 0 . rufipogon stricto sensu and rufipogon, var. nivara respectively. The ancient Austroasiatics were presumed to have acquired knowledge of rice agriculture from the ancient Hmong-Mien, and introgressive hybridisation with the already domesticated japonica were presumed to have introduced the traits sh4, rc and Prog1 into the nivara gene pool during or before this early contact phase.

The recent evidence presented by Molina et al. (2011) in support of a single domestication of Asian rice between 13,500 and 8200 years ago could simplify the 2009 hypothetical model. In the revised scenario, the ancient Hmong-Mien would still be the initial domesticators of rice, and the ancient Austroasiatics may still have acquired the technology secondarily, but this process would then have involved deriving indica from japonica rather than deriving indica from nivara rice. Moreover, an early contact phase lengthy enough to have left some linguistic residue no longer has to be assumed. However, at present, Molina et al. (2011) are unable to exclude the possibility that indica and japonica were independently domesticated, since the gene pools of the original wild precursors may have been lost or may still be inadequately represented by the samples hitherto studied by rice geneticists.

Interdisciplinary reconstructions of prehistory sometimes resemble a "château de cartes", and, as scientific theories, there would be nothing particularly disturbing about them falling over in the face of new evidence. Carefully reasoned interdisciplinary models of prehistory endowed with a transparent and clearly articulated argument structure consisting of discrete testable subsidiary hypotheses based on facts from the contributing disciplines can be precisely readjusted so as to accommodate new inputs readily. Indeed, models must be malleable enough to accommodate and incorporate new evidence. Models which cannot be thus adjusted must be discarded. In this context, it can apparently not be reiterated too often that

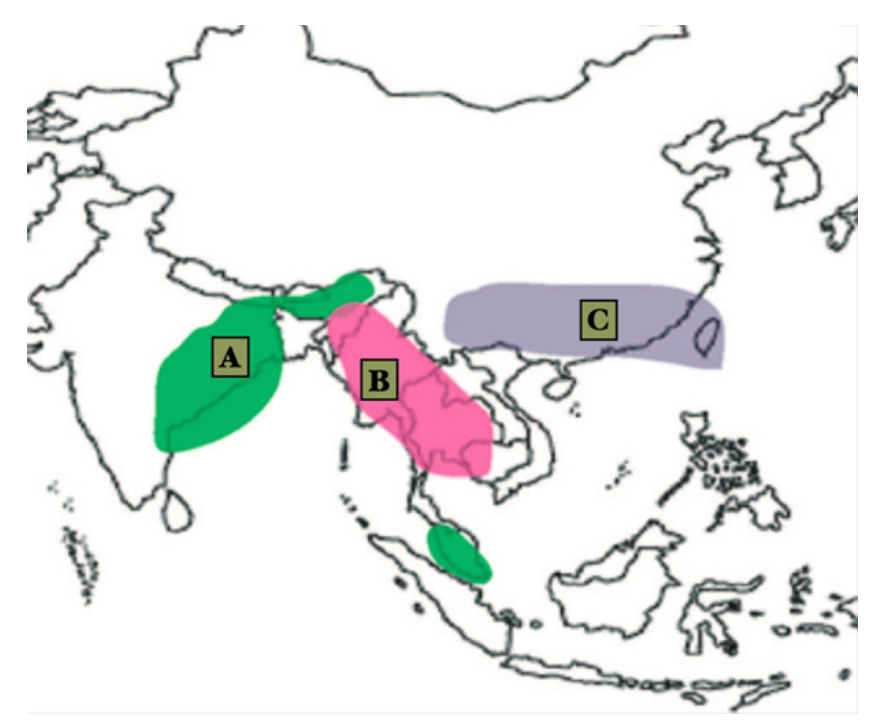

Fig. 2. The geographical ranges for the possible domestication of (A) ghaiyā or upland rice, (B) wet indica rice and (C) the japonica cultivar, based on the geographical distribution of genetic markers in the wild precursor Oryza rufipogon (adapted from Londo et al., 2006).

Fig. 2. Aires géographiques de la possible domestication du (A) ghaiyā ou riz pluvial, (B) riz cultivé indica et (C) riz cultivé japonica, basées sur la distribution géographique des marqueurs génétiques chez le précurseur sauvage Oryza rufipogon (adapté d'après Londo et al., 2006).

a proto-language can only be reconstructed on the basis of linguistic evidence, and that the linguistic ancestors of any modern language community were not necessarily all the same people as the community's biological forebears.

The linguistic evidence has singled out the linguistic ancestors of the Hmong-Mien and the Austroasiatic language communities as the likeliest candidates for the original domesticators of Asian rice. Yet this leaves us with the matter of localising the putative Hmong-Mien and Austroasiatic homelands in time and space. The modern distribution of Hmong-Mien language communities is shown in Fig. 1. The communities in Southeast Asia are generally more recent settlements, and mainland East Asia south of the Yangtze is the Hmong-Mien heartland. The ancient Hmong-Mien probably lived along much of the Yangtze river basin, where the currently available archaeological evidence would suggest that japonica rice was domesticated.

Rice genetics is, in fact, in partial disagreement with the inherently fragmentary archaeological record. Londo et al. (2006) identified three probable geographical ranges for the domestication of Asian rice on the basis of the geographical distribution of genetic markers in the wild precursor O. rufipogon (Fig. 2). Only one of the three regions has been subject to systematic palaeobotanical investigation. Moreover, the phylogenetic evidence adduced in support of a single domestication of Asian rice indicates that the "Indian/Indo-Chinese" population of rufipogon rice was directly ancestral to the first domesticated rice (Molina et al., 2011). The plot of the story will no doubt change as new data pour in from the different disciplines, and in this context it is relevant now to reassess some of the other linguistic palaeontological data for Austroasiatic. 
3

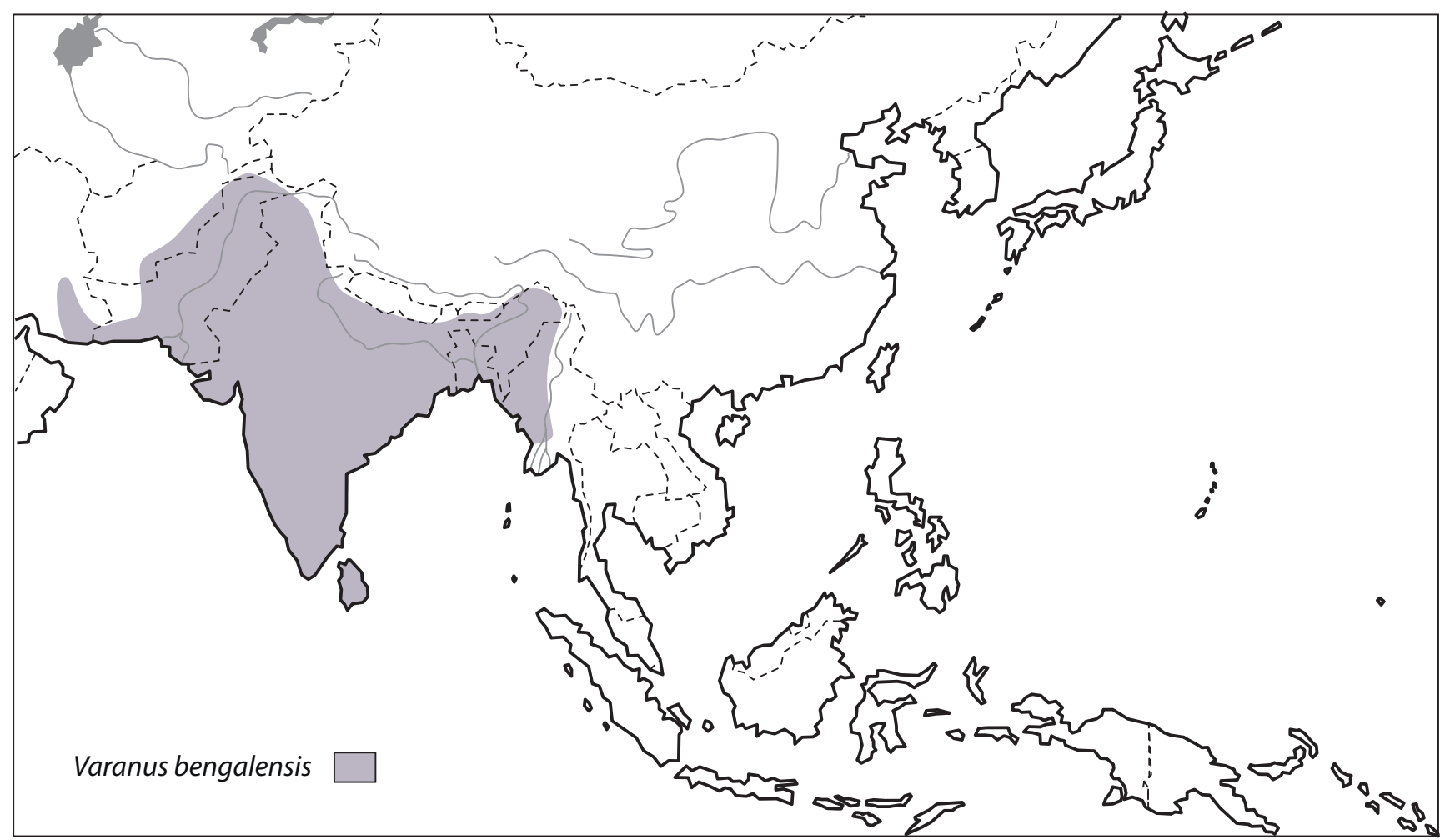

4

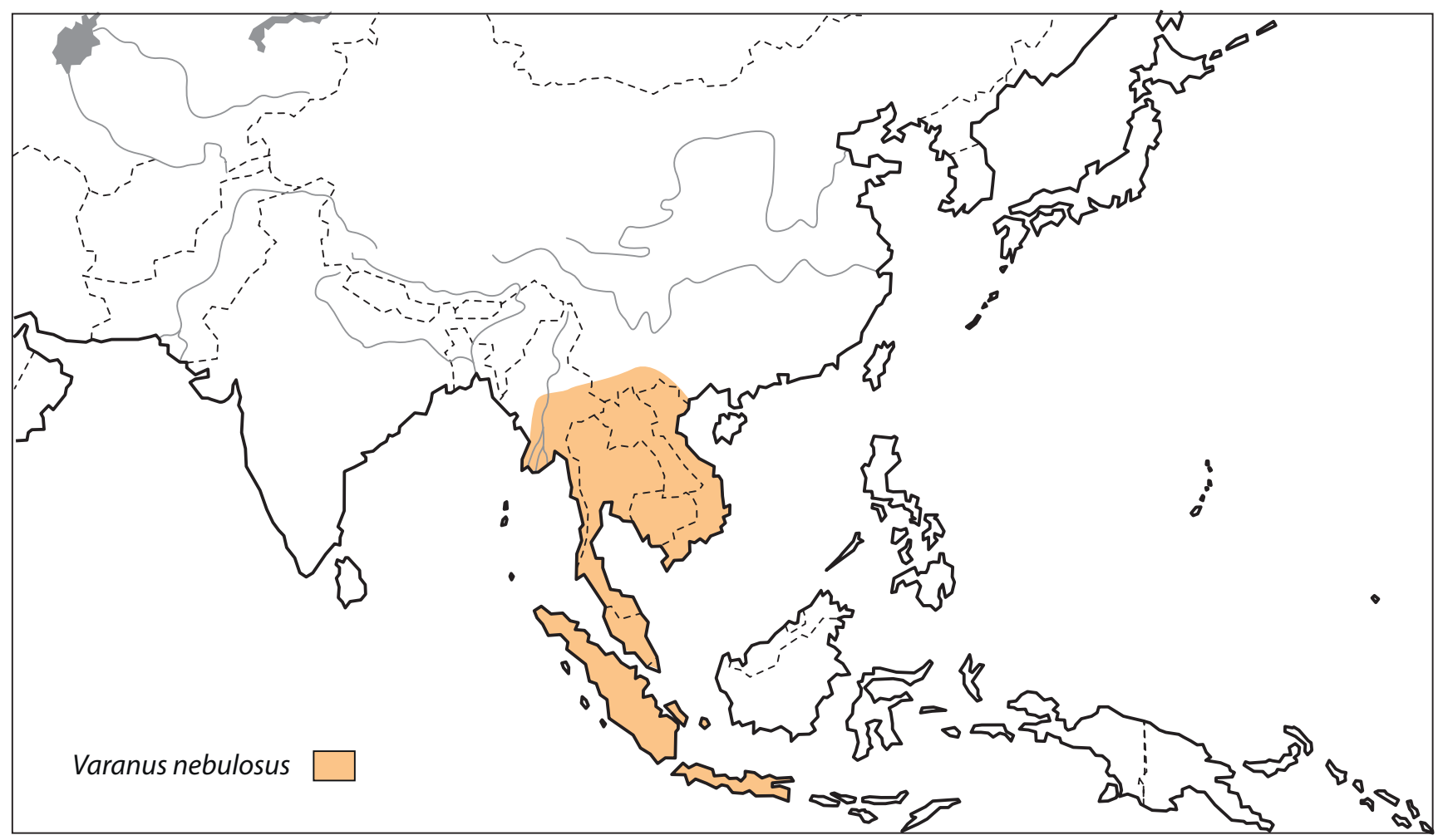

Fig. 3-18. The Holocene geographical ranges for animal species with reconstructible Proto-Austroasiatic names: (3) Varanus bengalensis; (4): Varanus nebulosus; (5): Pavo cristatus; (6): Pavo muticus; (7): Rhinoceros unicornis; (8): Rhinoceros sondaicus; (9): Dicerorhinus sumatrensis; (10): Manis pentadactyla; (11): Manis javanica; (12): Rhizomys sumatrensis; (13): Rhizomys sinensis; (14): Rhizomys pruinosus; (15): Bubalus bubalus; (16): Capricornis sumatrensis; (17): Arctitis binturong; (18): Elephas maximus (drawings kindly provided by Anne-Marie Bacon after Corbet and Hill (1992), and realised by Danièle Fouchier). Fig. 3-18. Aires géographiques holocènes des espèces animales avec les noms proto-austroasiatiques reconstruits : (3): Varanus bengalensis ; (4): Varanus nebulosus ; (5): Pavo cristatus; (6): Pavo muticus ; (7): Rhinoceros unicornis ; (8): Rhinoceros sondaicus ; (9): Dicerorhinus sumatrensis ; (10): Manis pentadactyla; (11): Manis javanica; (12): Rhizomys sumatrensis; (13): Rhizomys sinensis ; (14): Rhizomys pruinosus ; (15): Bubalus bubalus ; (16): Capricornis sumatrensis; (17): Arctitis binturong; (18): Elephas maximus (dessins fournis par Anne-Marie Bacon d'après Corbet et Hill (1992), et réalisés par Danièle Fouchier). 


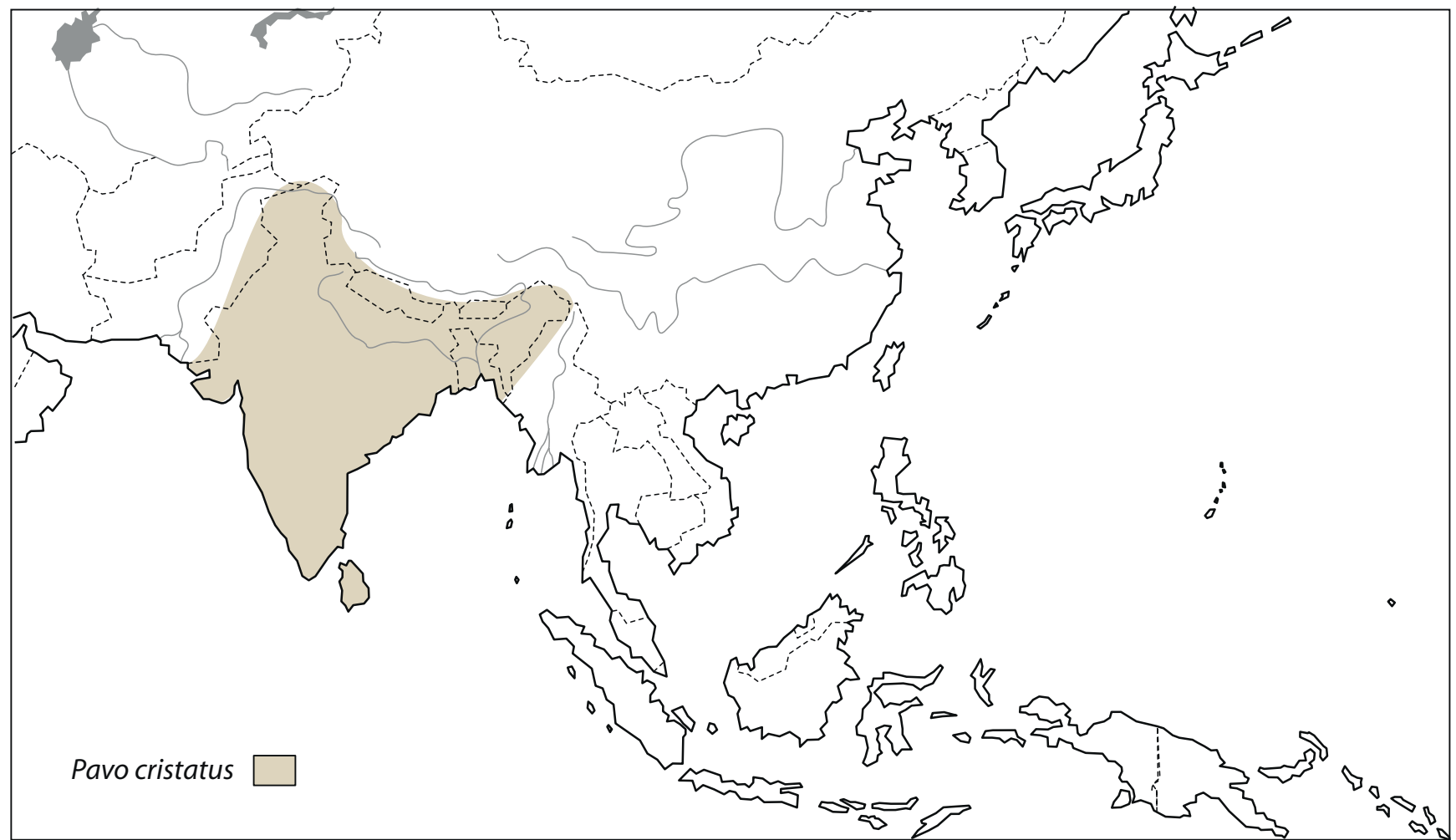

6

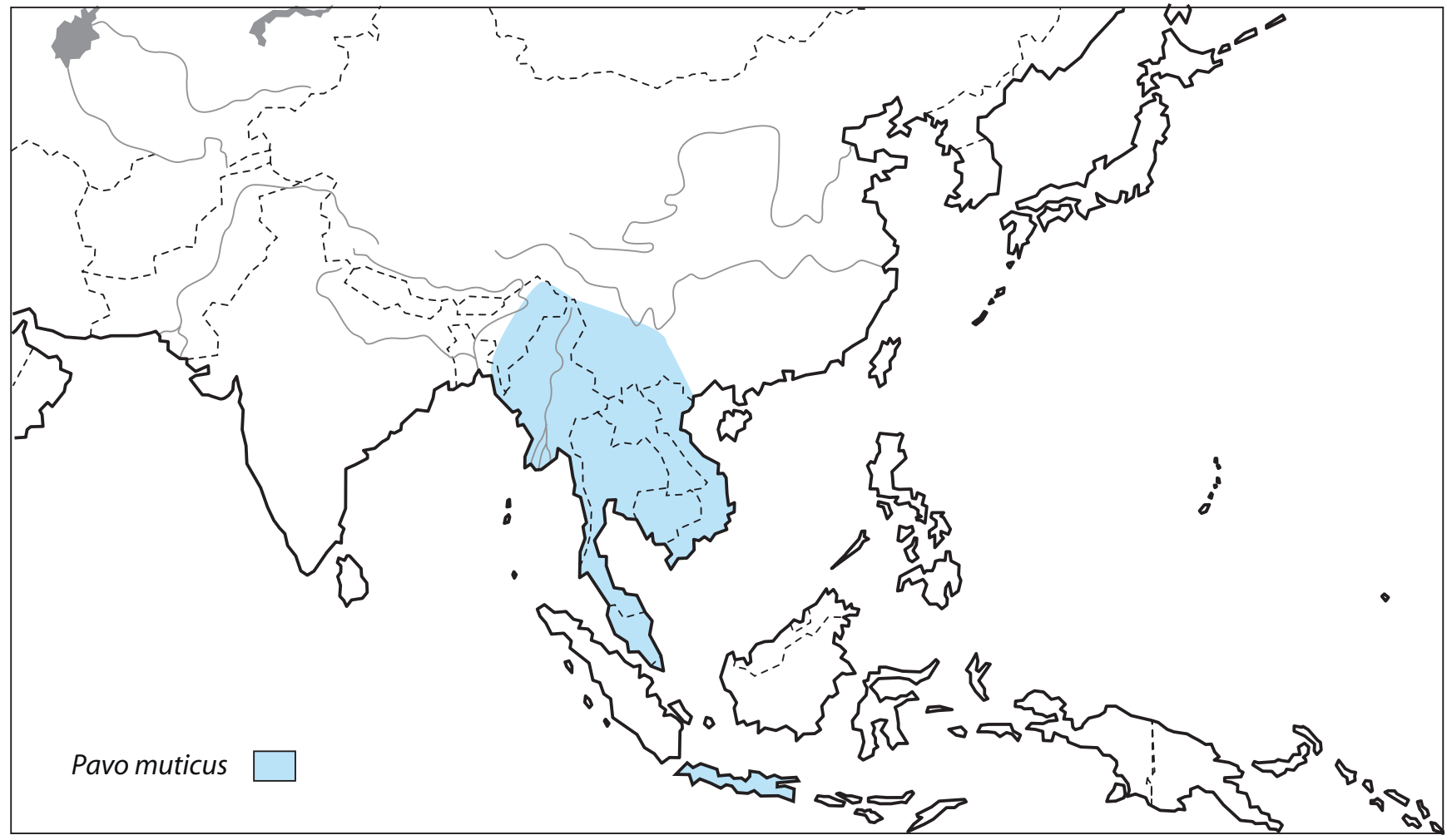

Fig. 3-18. (Continued).

Fig. 3-18. (Continued).

\section{The Austroasiatic homeland}

Scholars have sought to situate the Austroasiatic Urheimat as far west as the Indus valley and as far east as the Yangtze delta or insular Southeast Asia. Today, the principal contenders for the Austroasiatic homeland are the Indian subcontinent, the Bay of Bengal littoral, mainland Southeast Asia and the middle Yangtze. The gaping lacunae in palaeobotanical research are convenient to the argument in favour of the middle Yangtze. Linguistically, 


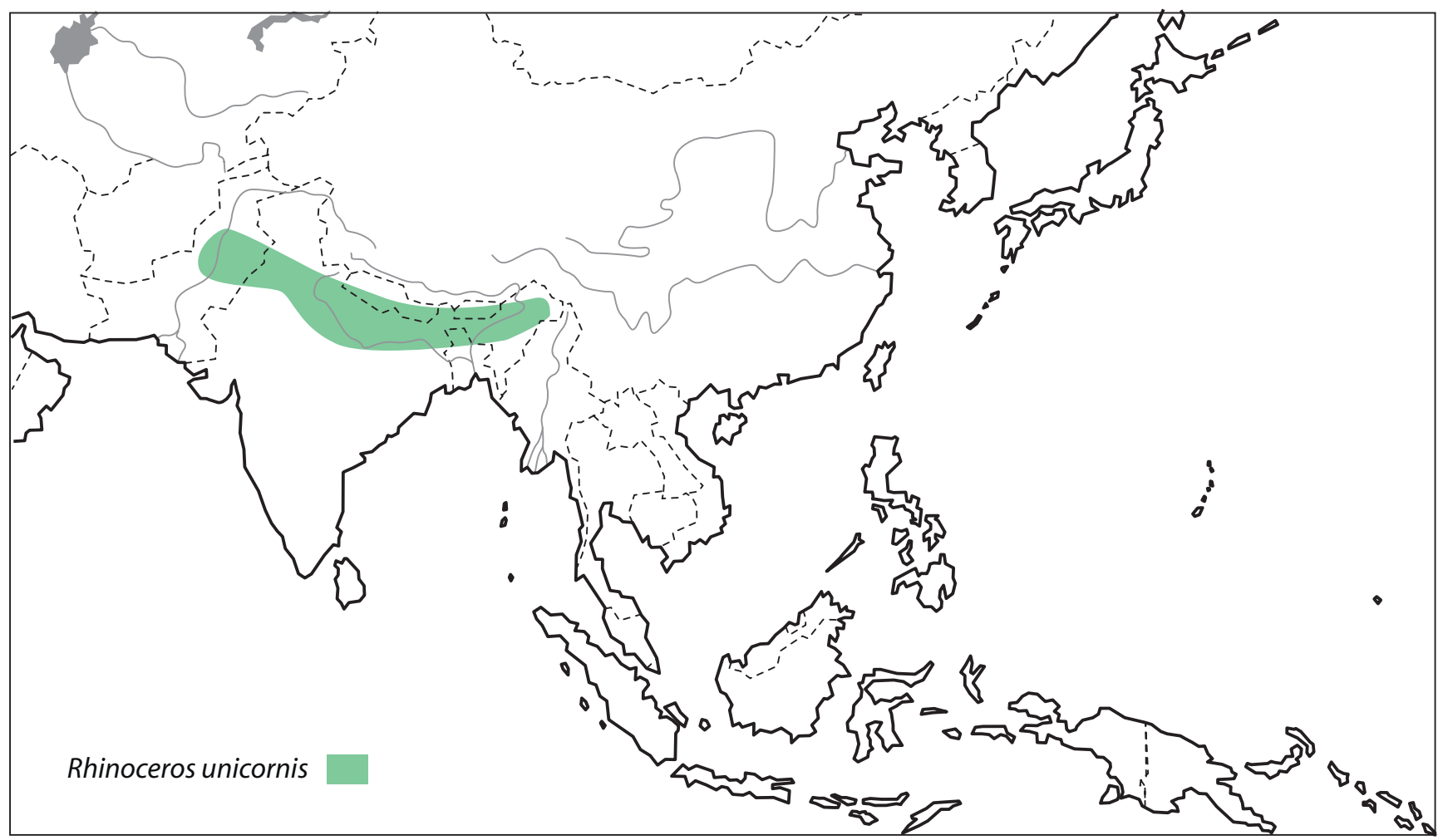

\section{8}

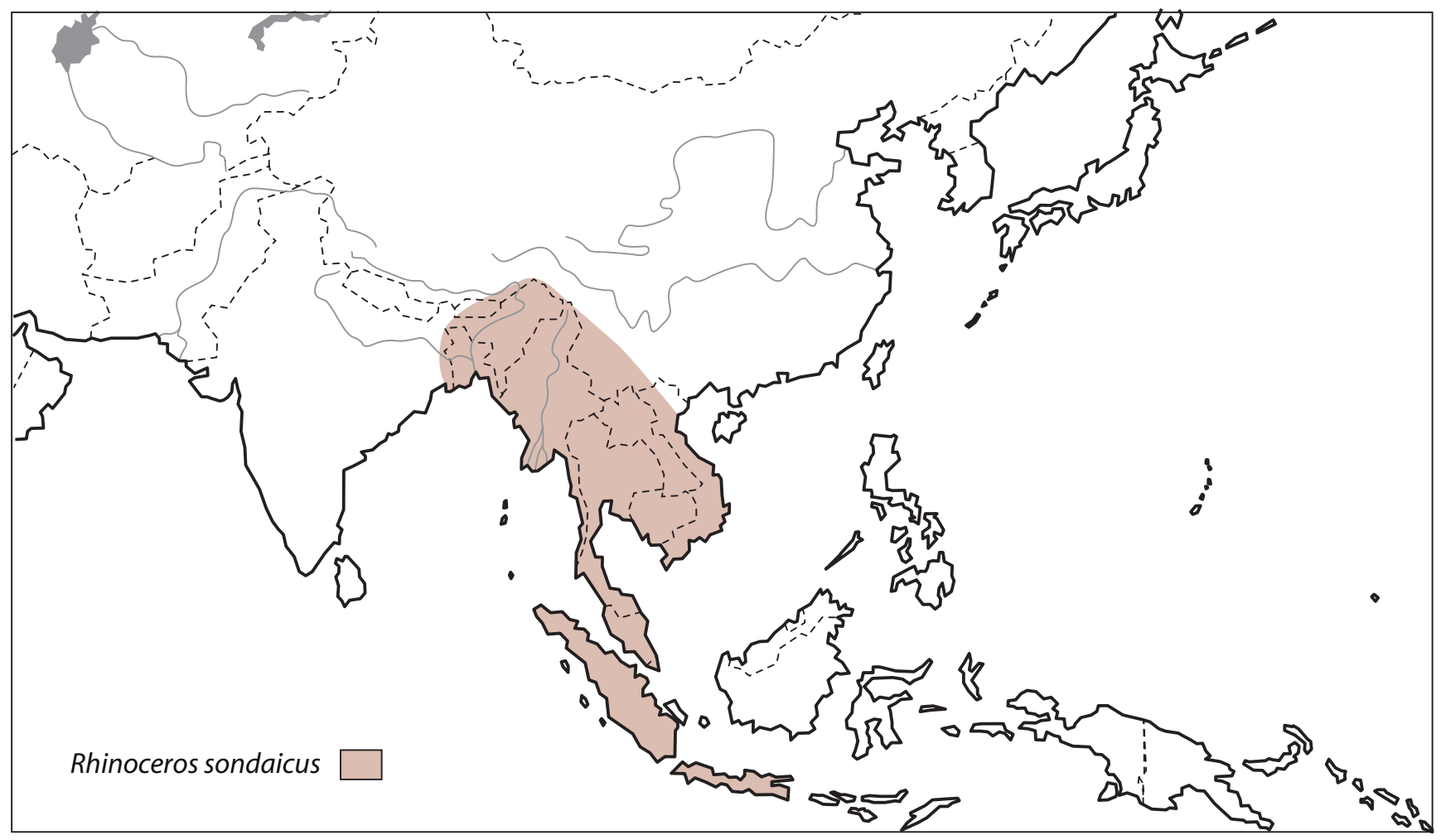

Fig. 3-18. (Continued).

Fig. 3-18. (Continued).

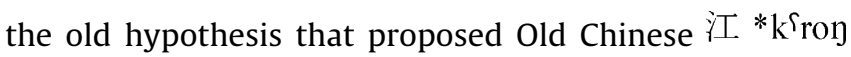
(jiāng) "Yangtze" to be a loan from Austroasiatic emboldened Pulleyblank (1983) to envision a major Austroasiatic presence all along the eastern seaboard from Việtnam to
Shāndōng, and to impute an Austroasiatic ethnolinguistic identity to the Lóngshān horizon. This interpretation of the linguistic data has notably been challenged by Zhāng (1998). 


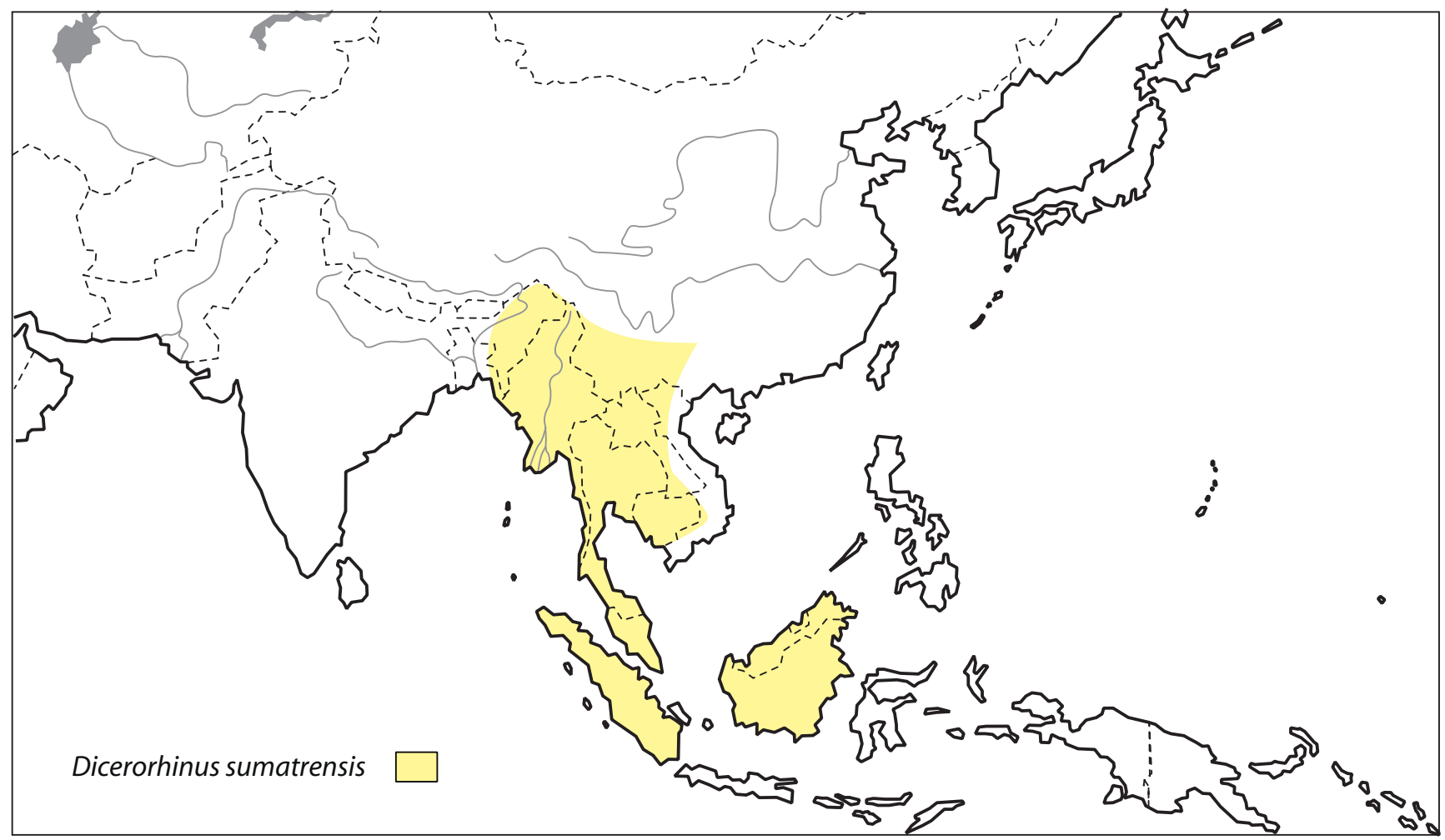

10

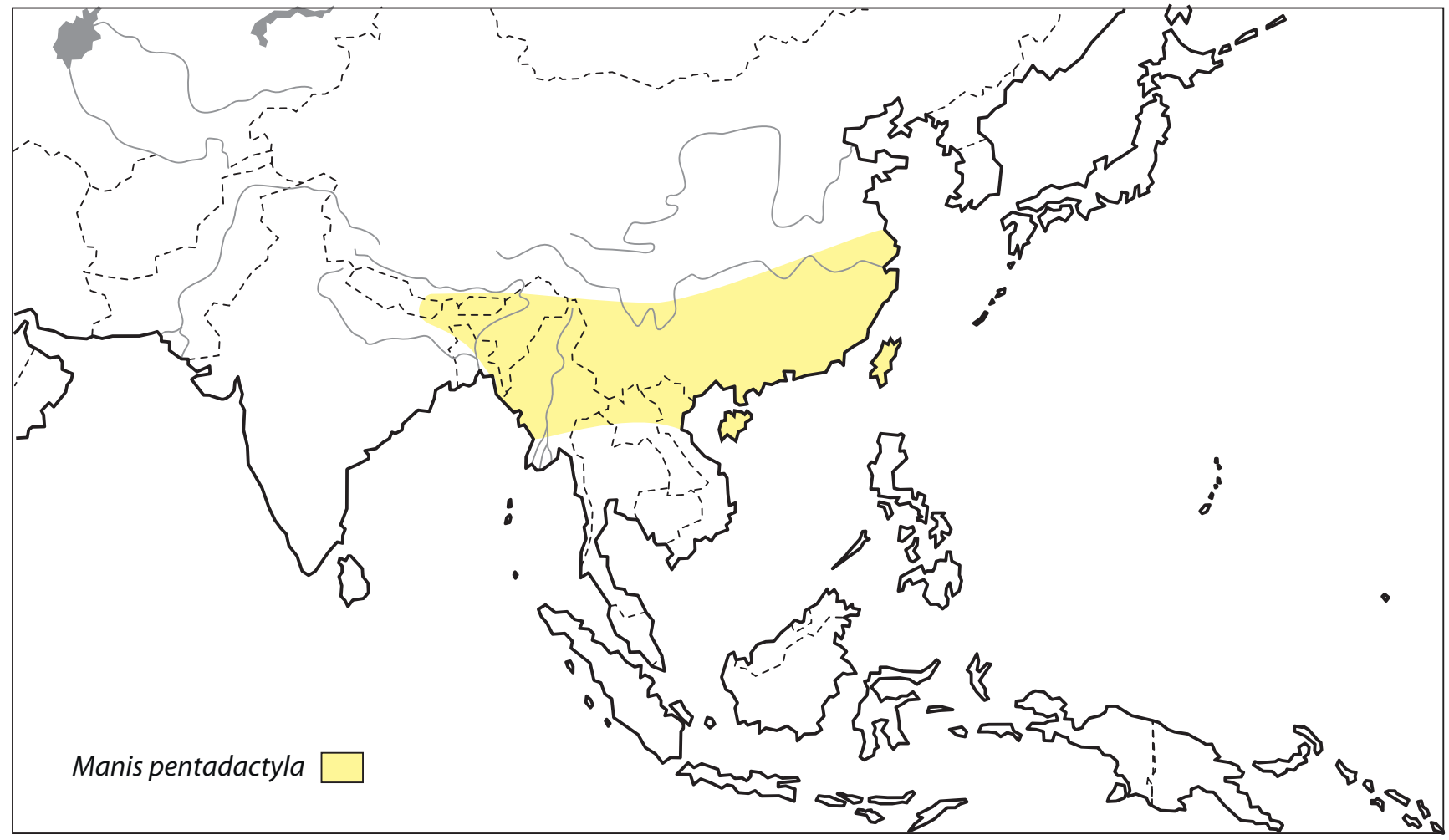

Fig. 3-18. (Continued).

Fig. 3-18. (Continued).

As opposed to this gossamer evidence, nine solidly reconstructible etyma in the ancient Austroasiatic lexicon adduced by Diffloth paint the picture of the fauna and ecology of a tropical humid homeland environment: *mra:k "peacock Pavo muticus", *tərkuət "tree monitor
Varanus nebulosus or bengalensis", *tənyu:? "binturong Arctitis binturong", *(bən)jo:l *j(ərm)o:1 "pangolin Manis javanica", *dəkan "bamboo rat Rhizomys sumatrensis", *kacian "the Asian elephant Elephas maximus", *kiac "mountain goat Capricornis sumatrensis", *rəma:s 
11

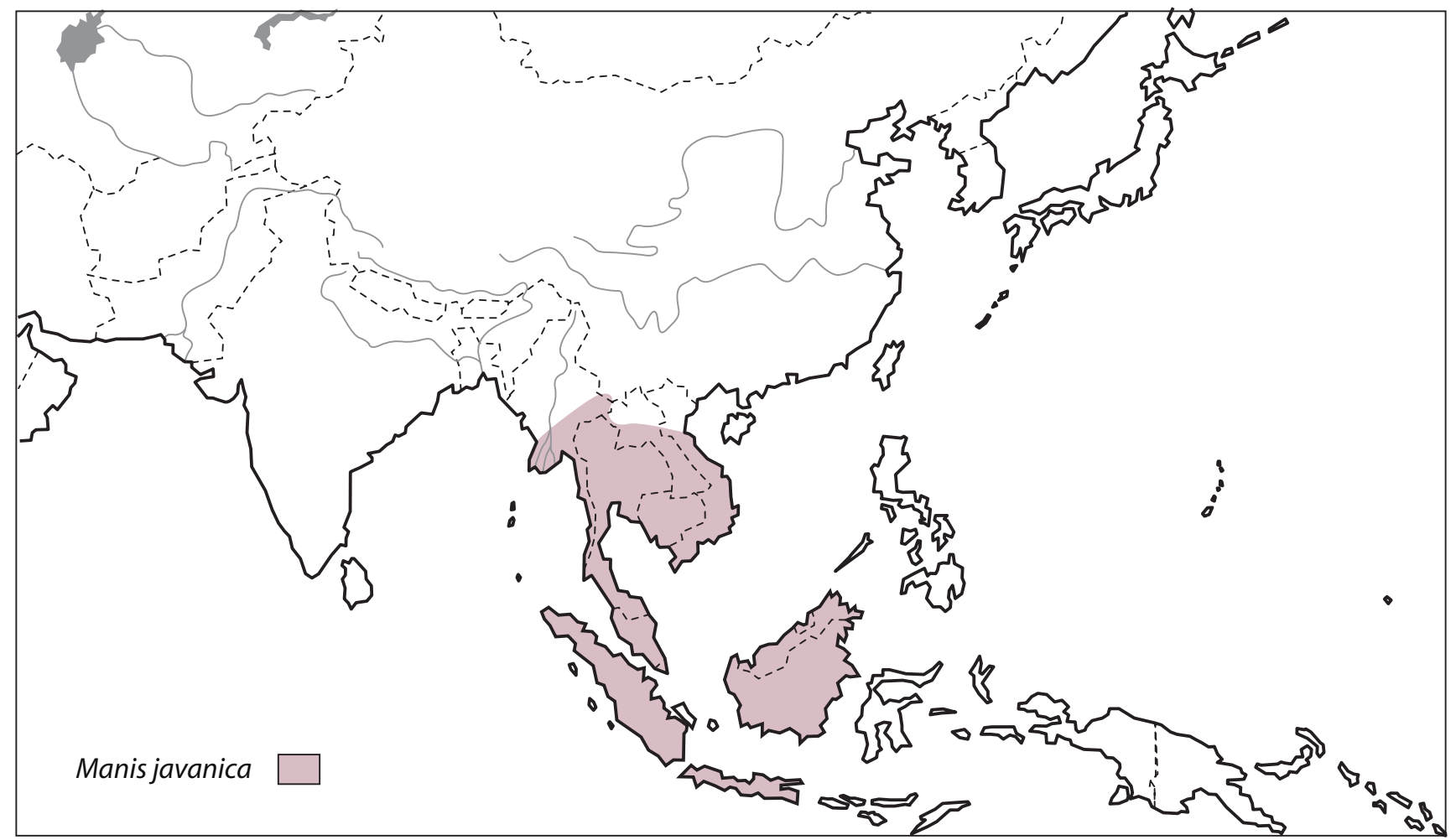

\section{2}

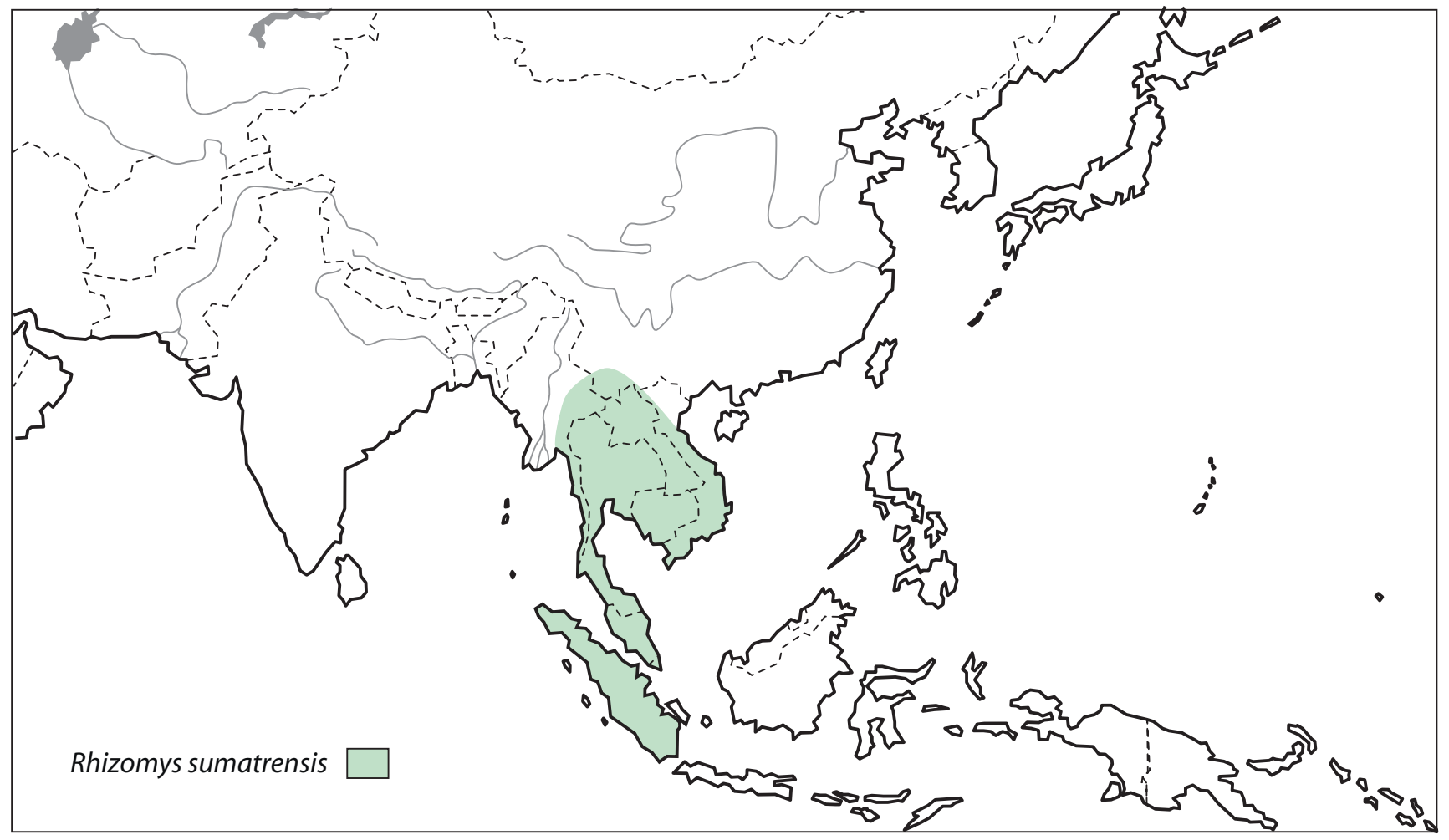

Fig. 3-18. ( Continued).

Fig. 3-18. (Continued).

"rhinoceros Dicerorhinus sumatrensis" and *tənriak "buffalo Bubalus bubalus" (Diffloth, 2005: 78). The Austroasiatic root *d əkan "bamboo rat" has found its way into Malay as a loan, but this does not affect the picture. Diffloth has argued that all of these species were never native to what today is China. This evidence therefore rendered the middle Yangtze homeland hypothesis less likely.

However, Diffloth offers both the Bengal tree monitor Varanus bengalensis and the clouded tree monitor Varanus nebulosus as possible referents for the 


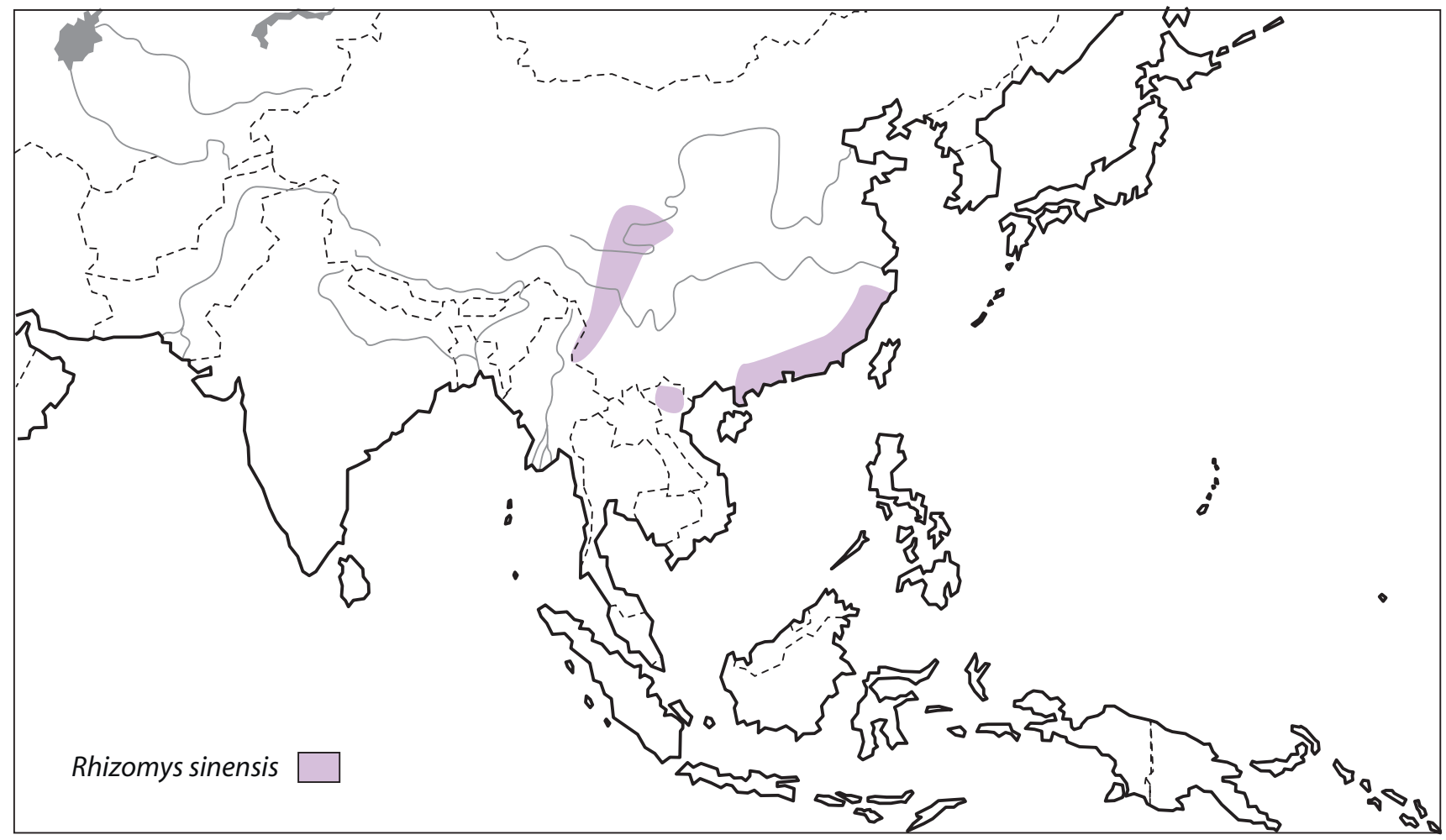

14

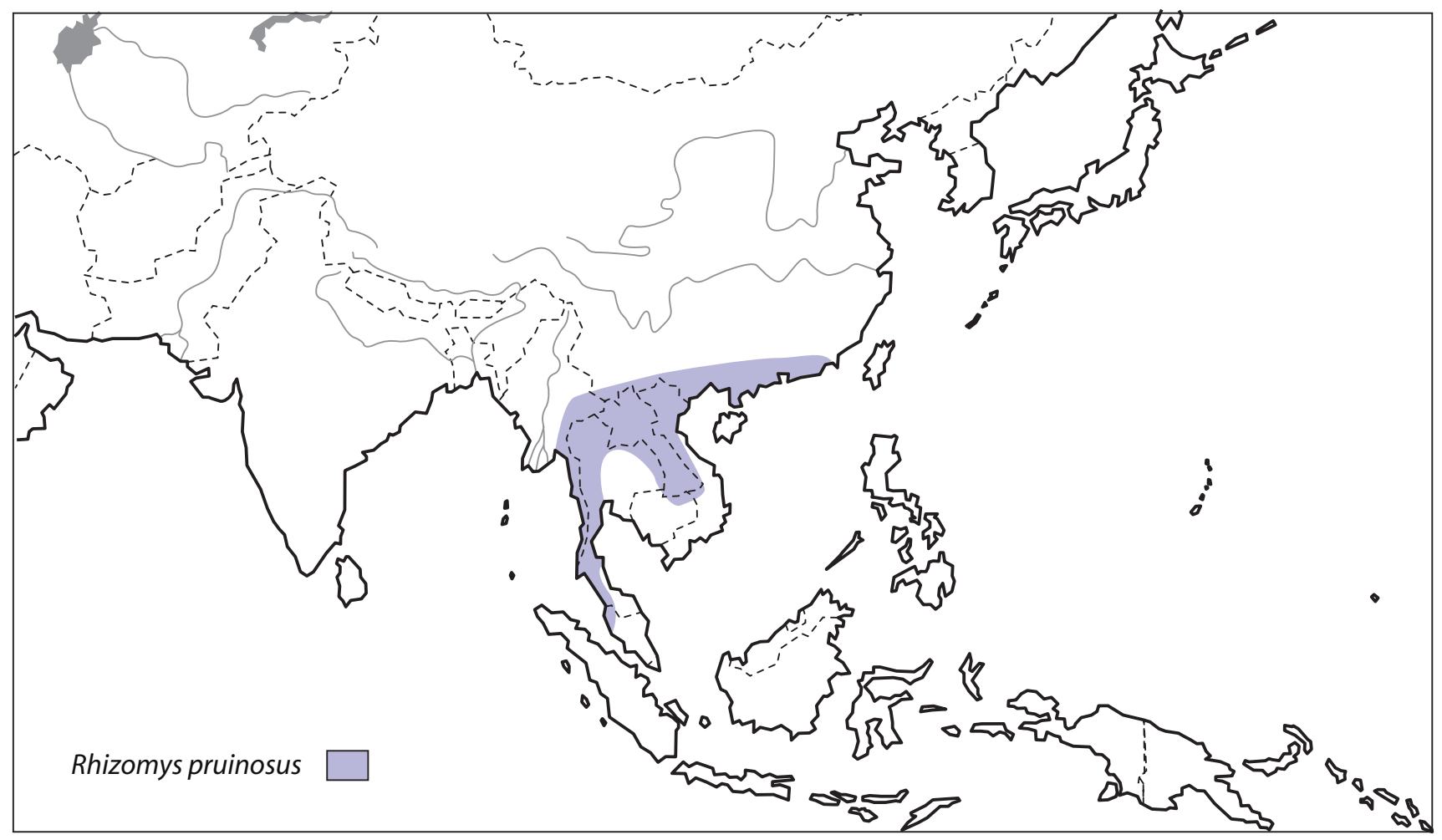

Fig. 3-18. (Continued).

Fig. 3-18. (Continued).

Austroasiatic etymon *tərkuət . By the same token, it could be argued that the ancient Austroasiatics may have used the root*mra:k just as aptly to refer to the Indian peafowl Pavo cristatus as to the Javan peafowl Pavo muticus, and that they may have used the root *rəma:s just as readily to refer to the Indian rhinoceros Rhinoceros unicornis or Javan rhinoceros Rhinoceros sondaicus as to the Sumatran rhinoceros Dicerorhinus sumatrensis. The Holocene distribution maps of the tree monitor*torkuət (Figs. 3 and 4), the peafowl *mra:k (Figs. 5 and 6 ) and the rhinoceros *rəma:s 
15

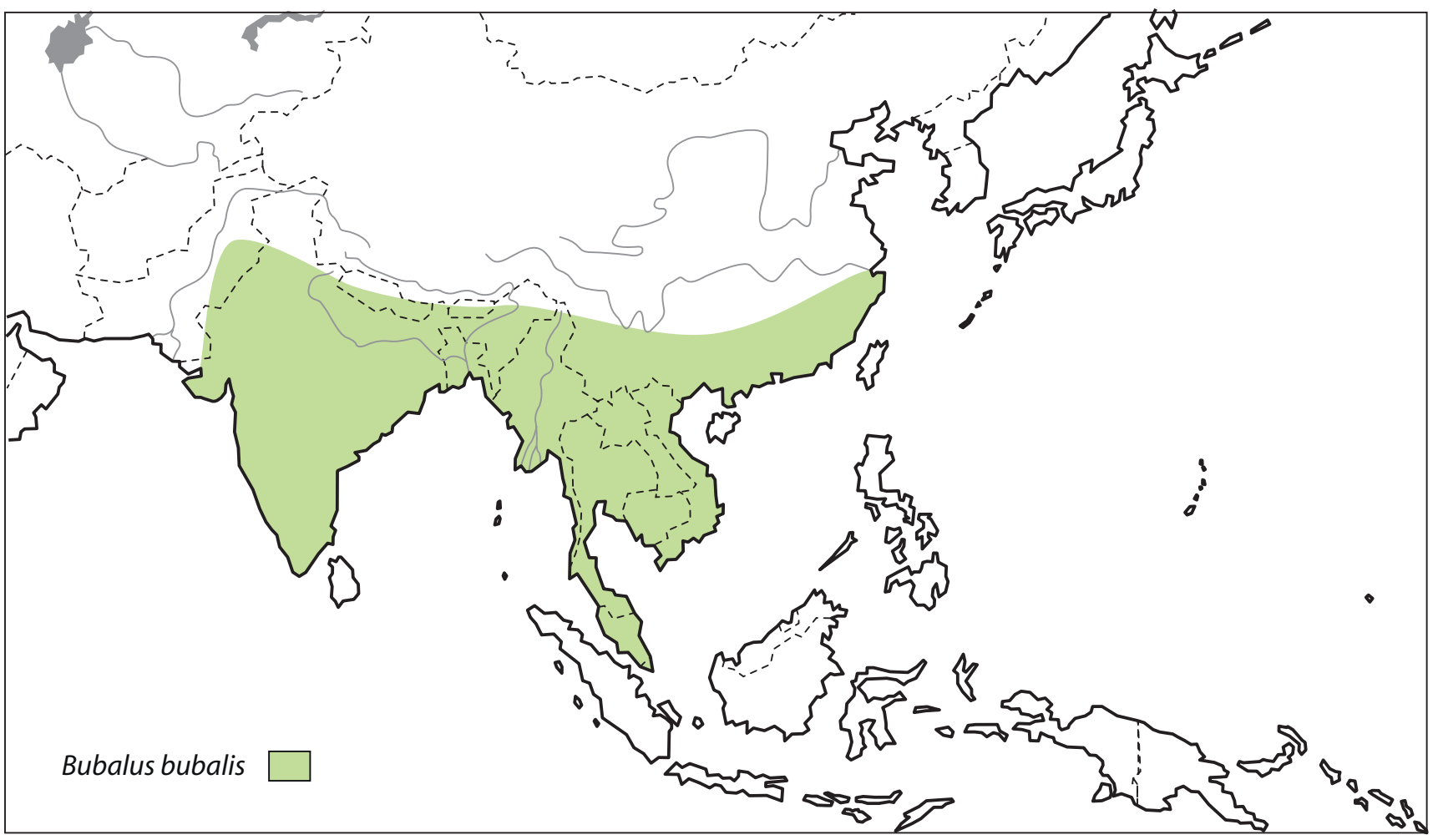

16

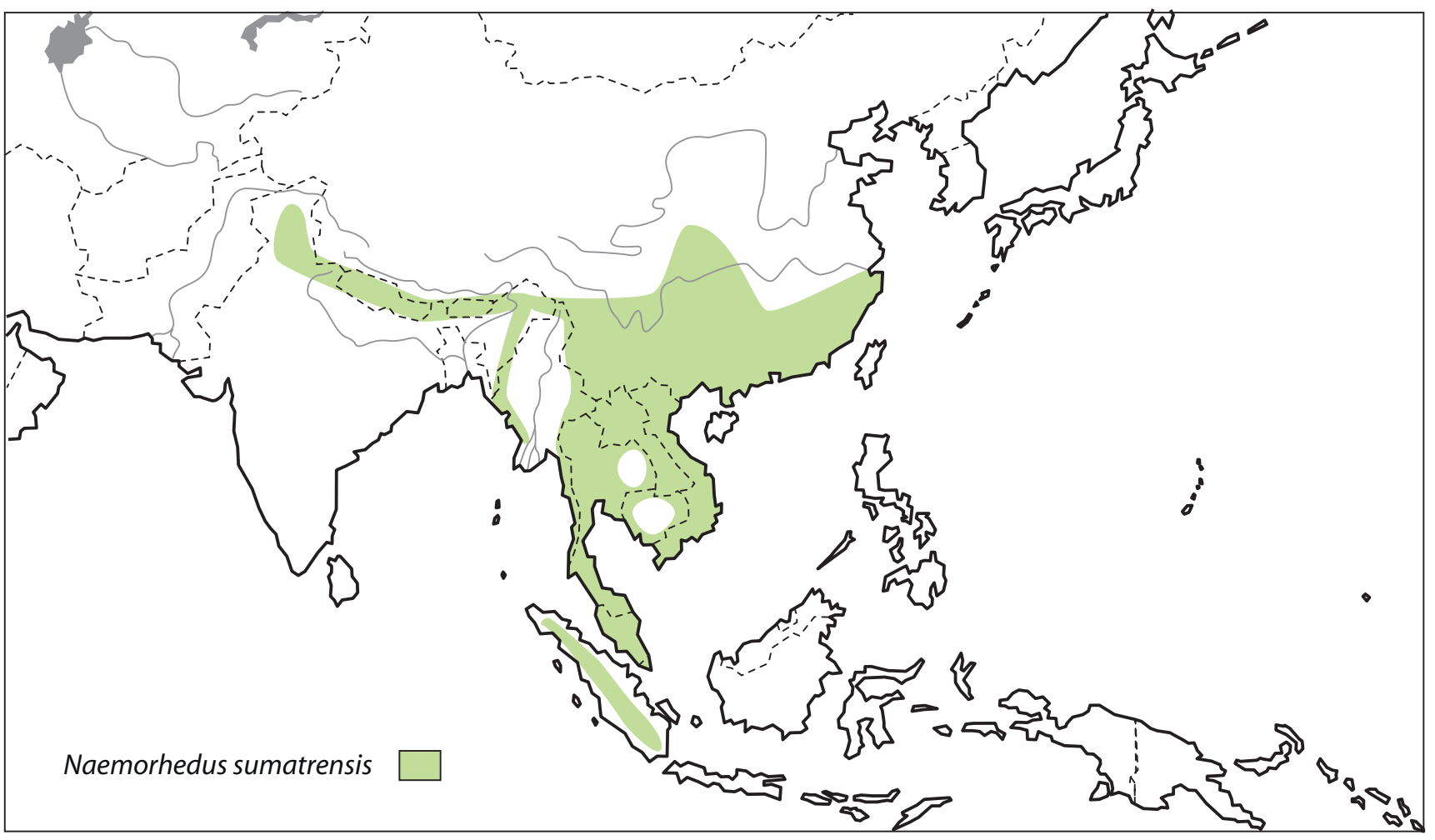

Fig. 3-18. (Continued).

Fig. 3-18. (Continued).

(Figs. 7-9) cover Southeast Asia, including the Chinese province of Yúnnán and Northeastern India, though the rhinoceros would exclude the Deccan plateau and indeed much of the subcontinent.
Even if we presume that semantic shifts were limited to species that to jungle dwelling humans resembled each other closely, then for the Austroasiatic root *(bən)jo:l *j(ərm)o:l, the Late Holocene geographical 


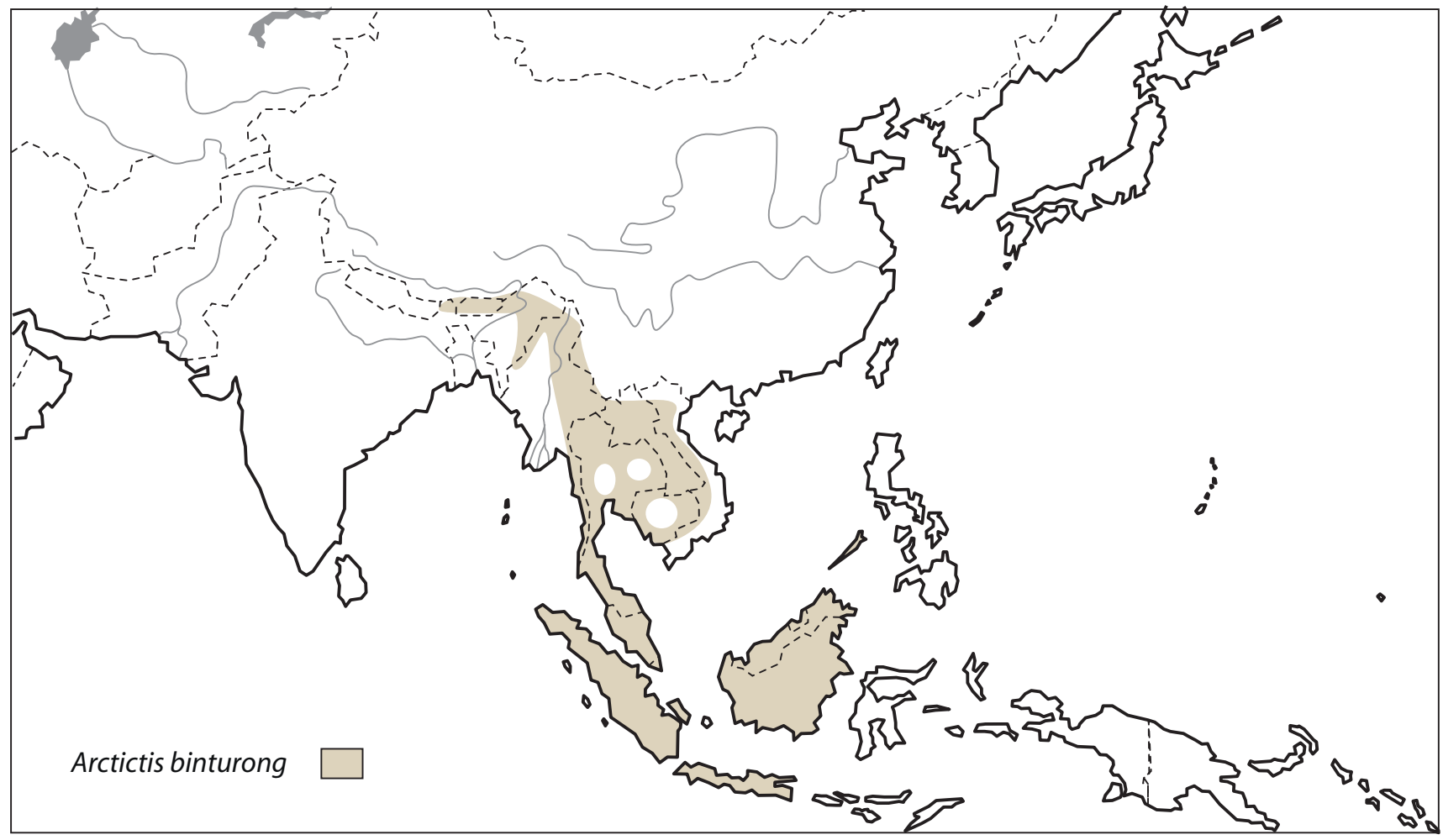

18

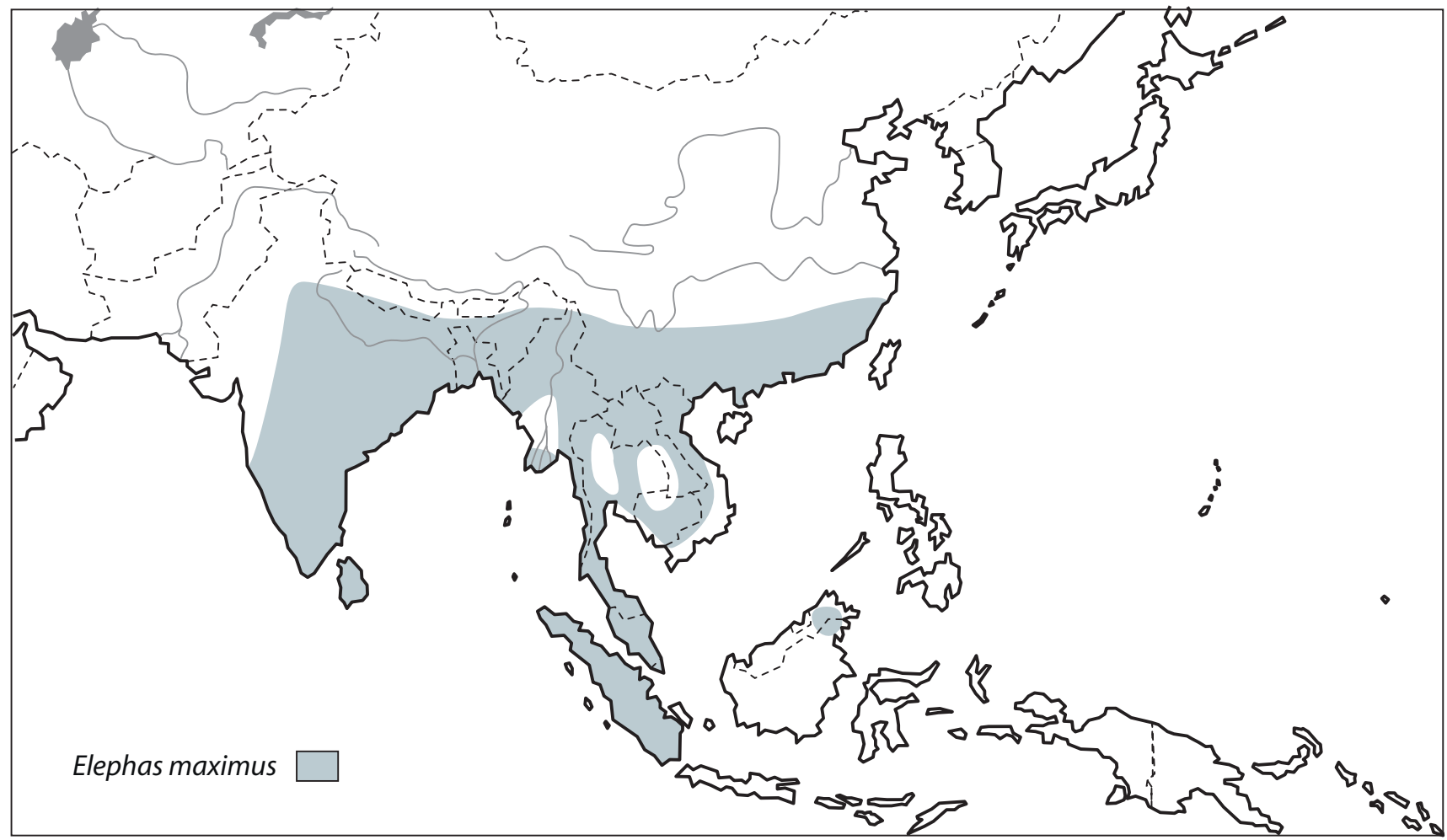

Fig. 3-18. (Continued).

Fig. 3-18. (Continued).

distribution of the Chinese pangolin Manis pentadactyla would be just as relevant as the geographical range of the Sunda pangolin Manis javanica. The geographical distribution of the pangolin *(bən)jo:l $\sim$ *j(ərm)o:1 (Figs. 10 and 11) comprises all of Southeast Asia as far as the Wallace line as well as the northeastern Subcontinent at least as far east as the Nepalese district of Dolakhā, where I recently saw a pangolin, and East Asia south of the Yangtze, including the region around the mouth of the Yangtze. 


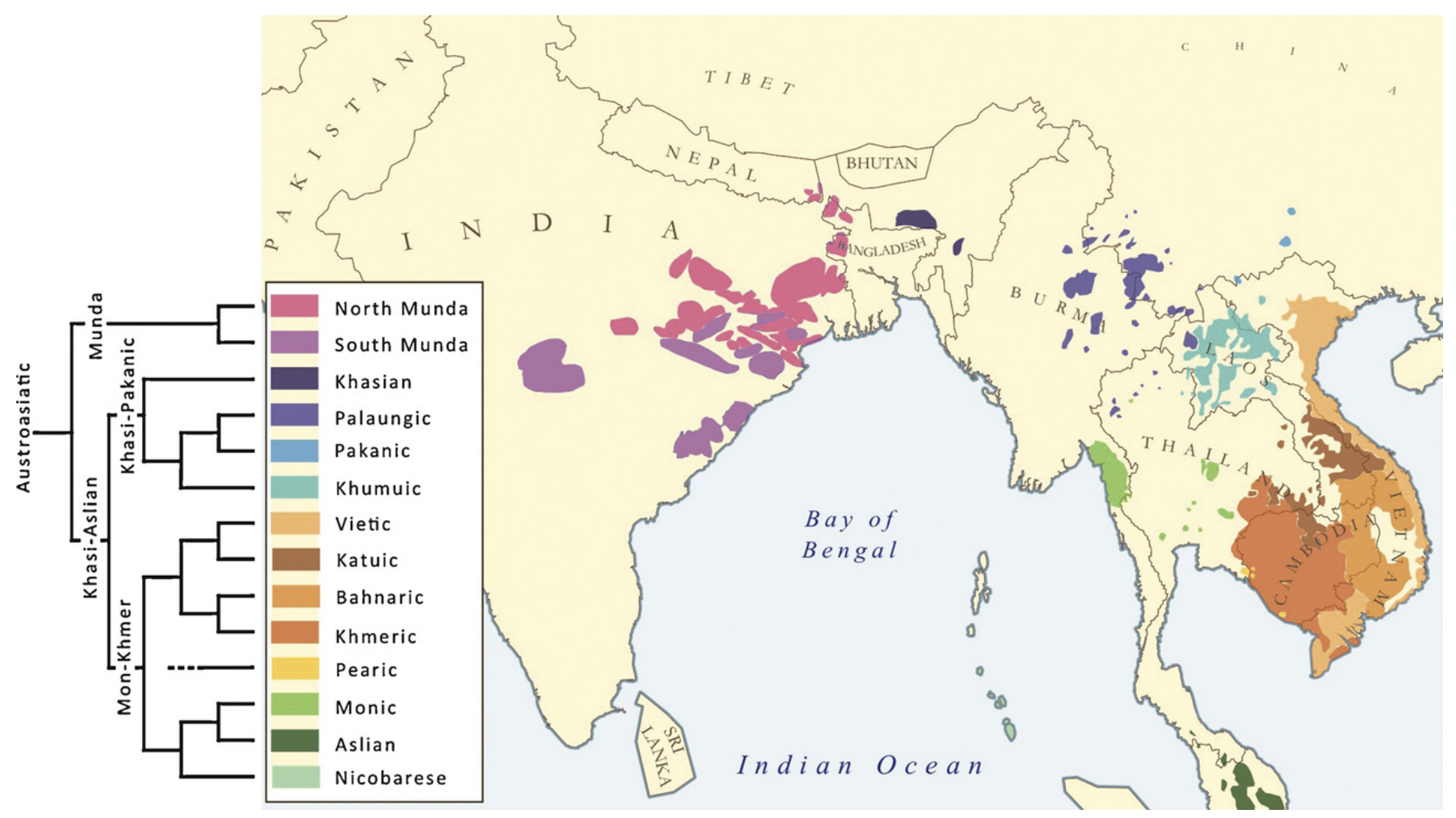

Fig. 19. Gérard Diffloth's revised (2009) Austroasiatic phylogeny and the geographical distribution of Austroasiatic languages, adapted from Chaubey et al. (2010). The two trunks of the Austroasiatic phylum are Munda, in Eastern, Northeastern and Central India, and Khasi-Aslian, which stretches from the Meghālaya in the northeast of the subcontinent to the Nicobars, the Malay peninsula and the Mekong delta in Southeast Asia. The precise phylogenetic position of Pearic within Mon-Khmer remains uncertain.

Fig. 19. Phylogénie austroasiatique révisée par Gérard Diffloth (2009) et distribution géographique des langues austroasiatiques, adaptées de Chaubey et al. (2010). Les deux branches du phylum austroasiatique sont Munda, à l'est, au nord-est et au centre de l'Inde, et Khasi-Aslian, qui s'étend depuis le Meghālaya dans le nord-est du sous-continent jusqu'aux îles nicobaraises, la péninsule malaise et le delta du Mékong dans le sud-est de l’Asie. La position phylogénétique précise du Pearic parmi le Mon-Khmer reste incertaine.

Likewise, for the root *dəkan, the range of the large bamboo rat Rhizomys sumatrensis may be augmented by the geographical ranges of the Chinese bamboo rat Rhizomys sinensis and the hoary bamboo rat Rhizomys pruinosus. These enlargements increase the range of possible referents for the bamboo rat etymon *dəkan, (Figs. 12-14), to comprise most of Southeast Asia and parts of mainland East Asia. As linguistic palaeontological evidence, however, this less salient species is inherently more problematic, since arguably this etymon could be transferred to any large rodent or even other small mammal.

The Holocene geographical distribution of the buffalo *tənriak (Fig. 15) and the Asian elephant *kaciay (Fig. 18) cover all of South and Southeast Asia as well as East Asia south of the Yangtze. The Holocene geographical range of the serow *kiac (Fig. 16) covers Southeast Asia, East Asia south of the Yangtze as well as the Himalayas and the IndoBurmese borderlands. The binturong *tənyu:? (Fig. 17) covers mainland and insular Southeast Asia all the way to the Wallace line as well as Northeastern India and the IndoBurmese borderlands. In summary, the Holocene ranges of the species for which Austroasiatic has reconstructible etyma covers a vast area. The area of overlap delineated by the reconstructible fauna, however, more specifically comprises Northeastern India, the Indo-Burmese borderlands and Burma.
Linguistic palaeontology is, of course, not the only linguistic tool for localising the original homeland of a language phylum. Both the centre of gravity of the phylum on the basis on the geographical distribution of modern Austroasiatic language communities as well as the deepest phylogenetic divisions in the family tree point to the northern Bay of Bengal littoral (Fig. 19). The deepest historical division in the family's phylogeny lies between Munda in the west and Khasi-Aslian in the east, which would put the homeland on either side of the Ganges and Brahmaputra delta. Even the deepest division within the Khasi-Aslian trunk, i.e. the split into Khasi-Pakanic and Mon-Khmer, would suggest a point of dispersal for Khasi-Aslian between South Asia proper and mainland Southeast Asia proper.

\section{Conclusion}

Recent phylogenetic evidence has been adduced in support of a single domestication of Asian rice, but the findings do not, at present, exclude the possibility that indica and japonica rice originated directly from different 0 . rufipogon gene pools. A single domestication of Asian rice would simplify the 2009 model by reducing the necessity of assuming an early contact phase between ancient Hmong-Mien and ancient Austroasiatics lengthy enough to have left 
some linguistic residue. Phylogenetic evidence appears to indicate that the Indian/Indo-Chinese population of rufipogon rice was directly ancestral to the first domesticated rice. By contrast, the currently available archaeological evidence at present favours the Yangtze river basin as the locus of the domestication of Asian rice. However, the gaping lacunae in the palaeobotanical research on rice domestication span vast stretches of unresearched territory, including key areas identified by rice geneticists as likely sites for the domestication of Asian rice. In some relevant areas, the recoverability of possible rice agriculture sites might be problematic. The linguistic palaeontological evidence supports Hmong-Mien for the linguistic identity of early domesticators of Asian rice, and the Yangtze river basin is a likely location for the Hmong-Mien homeland. The linguistic evidence indicates that the ancient Austroasiatics also cultivated rice and supports the view that the early Austroasiatics may have been the people behind an independent domestication of Asian rice. Additional linguistic evidence from the reconstructible Austroasiatic lexicon indicates an Austroasiatic homeland in the northern Bay of Bengal littoral, more specifically the northeastern portion of the Indian subcontinent, the Indo-Burmese borderlands and Burma.

\section{References}

Agrawal, D.P., 2002. The earliest pottery and agriculture in South Asia. In: Yoshinori, Y. (Ed.), The Origins of Pottery and Agriculture. Lusre Press and Roli Books, for the International Center for Japanese Studies, New Delhi, p. 81-88.

Benedict, P.K., 1972. Sino-Tibetan: a Conspectus. Cambridge University Press, Cambridge.

Blench, R.M., 2009. If agriculture cannot be reconstructed for Proto-SinoTibetan, what are the consequences? Paper presented at the 42nd Conference on Sino-Tibetan Languages and Linguistics at Chiang Mai.

Candolle, A.L.P., 1883. Origine des plantes cultivées, 285. Librairie Germer Ballière et Compagnie, Paris, pp.309-311.

Chaubey, G., Metspalu, M., Choi, Y., Mägi, R., Romero, I.G., Rootsi, S., Soares, P., van Oven, M., Behar, D.M., Hudjashov, G., Basu Mallick, C., Karmin, M., Nelis, M., Parik, J., Goverdhana Reddy, A., Metspalu, E., van Driem, G., Xue, Y., Tyler-Smith, C., Thangaraj, K., Singh, L., Remm, M., Richards, M.B., Mirazon Lahr, M., Kayser, M., Villems, R., Kivisild, T., 2010. Population genetic structure in Indian Austroasiatic speakers: the role of landscape barriers and sex-specific admixture. Molecular biology and evolution., doi:10.1093/molbev/msq28.

Corbet, G.B., Hill, J.E., 1992. The mammals of the Indomalayan region. Natural History Museum publications. Oxford University Press.

Crawford, G.W., Shen, C., 1998. The origins of rice agriculture: recent progress in East Asia. Antiquity 72, 858-866.

Cushman, R.D., 1970. Rebel haunts and lotus huts: problems in the ethnohistory of the Yao. Cornell University doctoral dissertation, Ithaca, New York.

Diffloth, G., 2005. The contribution of linguistic palaeontology to the homeland of Austroasiatic. In: Sagart, L., Blench, R., Sanchez-Mazas, A. (Eds.), The peopling of East Asia: putting together the archaeology, linguistics and genetics. Routledge Curzon, London, pp. 77-80.

Diffloth, G., 2009. More on Dvaravati Old Mon. Paper presented at the Fourth International Conference on Austroasiatic Linguistics. Mahidol University, Salaya.

Fuller, D.Q., Qin, L., 2009. Water management and labour in the origins and dispersal of Asian rice. World Archaeology 41 (1), 88-111.

Fuller, D.Q., Harvey, E., Qin, L., 2007. Presumed domestication? Evidence for wild rice cultivation and domestication in the fifth millennium BC of the Lower Yangtze region. Antiquity 81, 316-331.

Fuller, D.Q., Qin, L., Zheng, Y., Zhao, Z., Chen, X., Hosoya, L.A., Sun, G.P., 2009. The domestication process and domestication rate in rice: Spikelet bases from the Lower Yangtze. Science 323, 1607-1610.

Garris, A.J., Tai, T.H., Coburn, J., Kresovich, S., McCouch, S., 2005. Genetic structure and diversity in Oryza sativa L. Genetics 169, 1631-1638.
Hazarika, M. 2005. Neolithic culture of Northeast India with special reference to the origins of agriculture and pottery. Pune (Poona): unpublished Master's thesis, Deccan College.

Hazarika, M., 2006. Neolithic culture of Northeast India: a recent perspective on the origins of pottery and agriculture. Ancient Asia 1, 25-43.

Higham, C., Lu, T., 1998. The origins and dispersal of rice cultivation. Antiquity $72,867-877$.

Kovach, M.J., Sweeney, M.T., McCouch, S., 2007. New insights into the history of rice domestication. Trends in Genetics 23 (11), 578-587.

Kovach, M.J., Calingacion, M.N., Fitzgerald, M.A., McCough, S.R., 2009. The origin and evolution of fragrance in rice (Oryza sativa L.). Proceedings of the National Academy of Sciences of the United States of America 106 (34), 14444-14449.

Londo, J.P., Chiang, Y.C., Hung, K.H., Chiang, T.Y., Schaal, B.A., 2006. Phylogeography of Asian wild rice, Oryza rufipogon, reveals multiple independent domestications of cultuvated rice, Oryza sativa. Proceedings of the National Academy of Sciences of the United States of America 103 (25), 9578-9583.

Lu, T., 2006. The occurrence of cereal cultivation in China. Asian Perspectives 45 (2), 129-158.

Lu, T., 2009. Prehistoric coexistence: the expansion of farming society from the Yangtze River Valley to western South China. Asian Perspectives, Senri Ethnological Studies 74, 47-52.

Matisoff, J.A., 2003. Handbook of Proto-Tibeto-Burman. University of California Press, Berkeley.

Molina, J., Sikora, M., Garud, N., Flowers, J.M., Rubinstein, S., Reynolds, A., Huang, P., Jackson, S., Schaal, B.A., Bustamante, C.D., Boyko, A.R., Purugganan, M.D., 2011. Molecular evidence for a single evolutionary origin of domesticated rice. In: Proceedings of the National Academy of Sciences of the United States of America, www.pnas.org/cgi/doi/10.1073/pnas.1104686108.

Nakamura, S.I., 2010. The origin of rice cultivation in the Lower Yangtze region, China. Archaeological and Anthropological Sciences 2 (2), $107-113$.

Nasu, H., Momohara, A., Yasuda, Y., He, J., 2006. The occurrence and identification of Setaria italica (L.) P. Beauv. (foxtail millet) grains from the Chengtoushan site (ca. $5800 \mathrm{cal}$ B.P.) in central China, with reference to the domestication centre in Asia. Vegetation History and Archaeobotany 16 (6), 481-494.

Pal, J.N., 1990. The early farming culture of Northern India. Bulletin of Deccan College Post-Graduate and Research Institute 49, 297304.

Parsons, B.J., Newbury, H.J., Jackson, M.T., 1999. The genetic structure and conservation of aus, aman and boro rices from Bangladesh. Genetic Resources and Crop Evolution 46 (6), 587-598.

Pictet, A., 1859. Les origines indo-européennes ou les aryas primitifs : essai de paléontologie linguistique (première partie, seconde partie). Joël Cherbuliez, Paris.

Pulleyblank, E.G., 1983. The Chinese and their neighbours in prehistoric and early historic times. In: Keightley, D.N. (Ed.), The Origins of Chinese Civilization. University of California Press, Berkeley, pp. 411466.

Ratliff, M., 2004. Vocabulary of environment and subsistence and in the Hmong-Mien proto-language. In: Tapp, N., Michaud, J., Culas, C., Lee, G.Y. (Eds.), Hmong/Miao in Asia. Silkworm Books, Chiang Mai, p. 147-165.

Ratliff, M. 2010. Hmong-Mien Language History. Canberra: Pacific Linguistics.

Ruddiman, W.F., Guo, Z., Zhou, X., Wu, H., Yu, Y., 2008. Early rice farming and anomalous methane trends. Quatern. Sci. Rev. 27, 1291-1295.

Sharma, G.R., Misra, V.D., Mandal, D., Misra, B.B., Pal, J.N., 1980. Beginnings of agriculture: from hunting and food gathering to domestication of plants and animals. Abhinav Prakashan, Allahabad.

Strecker, D., 1987. The Hmong-Mien languages. Linguistics of the TibetoBurman Area 10 (2), 1-11.

Sweeney, M.T., McCouch, S.R., 2007. The complex history of the domestication of rice. Ann. Botany 100, 951-957.

van Driem, G., 2001. Languages of the Himalayas: an ethnolinguistic handbook of the greater Himalayan region, containing an introduction to the symbiotic theory of language, 2. Brill, Leiden.

van Driem, G., 2005. Tibeto-Burman vs. Indo-Chinese: implications for population geneticists, archaeologists and prehistorians. In: Sagart, L., Blench, R., Sanchez-Mazas, A. (Eds.), The peopling of East Asia: putting together the archaeology, linguistics and genetics. Routledge Curzon, London, pp. 81-106. 
van Driem, G., 2007. The diversity of the Tibeto-Burman language family and the linguistic ancestry of Chinese. Bull. Chinese Linguistics 1 (2), 211-270.

van Driem, G, in press. Rice and the Austroasiatic and Hmong-Mien homelands'. In: Enfield N.J. (Ed.), Dynamics of Human Diversity: The Case of Mainland Southeast Asia. Canberra: Pacific Linguistics, Chapter 16.

Vavilov, N.I., 1926. Centry proisxoždenija kulturnyx rastenij (Studies on the origin of cultivated plants), Trudy po Prikladnoj Botanike, Genetike i Selekcii. Bulletin of Applied Botany, Genetics and Plant Breeding 16 (2), 1-248 von Heine-Geldern, R., 1917. Kopfjagd und Menschenopfer in Assam und Birma und ihre Ausstrahlungen nach Vorderindien. Mitteilungen der Anthropologischen Gesellschaft in Wien XXXVII, 1-65.

Weber, S., Lehman, H., Barela, T., Hawks, S., Harriman, D., 2010. Rice or millets: early farming strategies in prehistoric central Thailand. Archaeological and Anthropological Sciences 2 (2), 79-88.

Zhāng, H., 1998. Chinese etyma for river. J. Chinese Linguistics 26 (1), 1-47.

Zhao, Z., 2010. New data and new issues for the study of the origin of rice agriculture in China. Archaeological and Anthropological Sciences 2 (2), 99-105. 